\title{
Hypoxia: The Force that Drives Chronic Kidney Disease
}

\author{
Qiangwei Fu, MD; Sean P. Colgan, PhD; and Carl Simon Shelley, DPhil
}

\begin{abstract}
In the United States the prevalence of end-stage renal disease (ESRD) reached epidemic proportions in 2012 with over 600,000 patients being treated. The rates of ESRD among the elderly are disproportionally high. Consequently, as life expectancy increases and the baby-boom generation reaches retirement age, the already heavy burden imposed by ESRD on the US health care system is set to increase dramatically. ESRD represents the terminal stage of chronic kidney disease (CKD). A large body of evidence indicating that CKD is driven by renal tissue hypoxia has led to the development of therapeutic strategies that increase kidney oxygenation and the contention that chronic hypoxia is the final common pathway to end-stage renal failure. Numerous studies have demonstrated that one of the most potent means by which hypoxic conditions within the kidney produce CKD is by inducing a sustained inflammatory attack by infiltrating leukocytes. Indispensable to this attack is the acquisition by leukocytes of an adhesive phenotype. It was thought that this process resulted exclusively from leukocytes responding to cytokines released from ischemic renal endothelium. However, recently it has been demonstrated that leukocytes also become activated independent of the hypoxic response of endothelial cells. It was found that this endothelium-independent mechanism involves leukocytes directly sensing hypoxia and responding by transcriptional induction of the genes that encode the $\beta 2$-integrin family of adhesion molecules. This induction likely maintains the long-term inflammation by which hypoxia drives the pathogenesis of CKD. Consequently, targeting these transcriptional mechanisms would appear to represent a promising new therapeutic strategy.
\end{abstract}

Keywords: Hypoxia; Kidney disease; Leukocyte adhesion; CD43; CD45; $\beta 2$-integrins; Gene transcription

$\mathrm{S}$ ince the beginning of renal replacement therapy for end stage renal disease (ESRD) through dialysis or transplantation, the number of patients treated for terminal kidney failure worldwide has continued to grow at an annual rate of approximately $7 \% .^{1-3}$ This is far in excess of the annual $1 \%$ growth rate of the world population in general. In 2012, a survey of 7 billion people spanning over 230 countries was undertaken. ${ }^{1}$ This survey found that 3,010,000 patients were being treated for ESRD. Of these, 652,000 were living with a donor organ, and 2,358,000 were on dialysis treatment.

In 2011, the United States spent over 49 billion dollars treating nearly eleven times more ESRD patients than in 1980. ${ }^{4}$ This trend shows no sign of slowing down. ${ }^{4}$ In 2003, the prevalence of chronic kidney disease (CKD) in the US adult population was $11 \%$ (19.2 million). Of these patients, an estimated 5.9 million individuals had stage $1 ; 5.3$ million had stage 2; 7.6 million had stage 3; 400,000 individuals had stage 4; and 300,000 individuals had stage 5 , or kidney failure. $^{5}$

The incidence of ESRD has already reached epidemic proportions in the United States. Furthermore, the rates of ESRD among the elderly are disproportionably high. Consequently, as life expectancy increases and baby-boomers retire, the already heavy burden imposed by ESRD on the US health care system is predicted to increase dramatically. 
The main cause of ESRD is CKD. This in turn is driven by a constellation of interlinked risk factors. Primary amongst these factors are anemia, ${ }^{6-9}$ diabetic hyperglycemia, ${ }^{10-12}$ hypertension, ${ }^{13-17}$ hypercholesterolemia, ${ }^{18-20}$ cigarette smoking, ${ }^{21-27}$ air pollution, ${ }^{28-42}$ atherosclerosis, ${ }^{43-52}$ repeated episodes of acute kidney injury, ${ }^{53-70}$ and sleep apnea. ${ }^{71-87}$ All the risk factors associated with CKD produce inappropriately low oxygen tensions within the kidney. On the basis of this association, Fine et $\mathrm{a}^{88}$ proposed in 2000 that chronic hypoxia is the final common pathway that leads to the development of end-stage renal failure. Subsequently, this theory has been validated by numerous studies. ${ }^{89-99}$ Particularly informative have been recent experiments where kidney oxygen tension has been reduced with dinitrophenol without affecting markers of oxidative stress. Under these circumstances urinary protein excretion, inflammatory cell infiltration into the kidney, and renal epithelial-to-mesenchymal transition were all increased. ${ }^{100,101}$ Consequently, there appears to be a direct link between hypoxia and the progression of CKD.

\section{Causes of Kidney Hypoxia}

In relation to their weight, the kidneys are the best-perfused organs of the body. ${ }^{102}$ Paradoxically, however, oxygenation of the renal parenchyma is poor, with oxygen tensions in the renal cortex averaging $30 \mathrm{~mm} \mathrm{Hg}$ and those in the renal medulla being below $10 \mathrm{~mm} \mathrm{Hg} .{ }^{103,104}$ The reason for this dramatic contrast between oxygen supply and oxygenation is due both to the way the kidney is built and to the function it performs. With regard to kidney structure, arterial and venous pre-glomerular and post-glomerular vessels run strictly parallel and in close contact to one another over long distances. This parallel architecture drives the diffusion of oxygen from arterioles to the post-capillary venous system before it can enter the capillary bed. ${ }^{104,105}$ Compounding the problem of oxygen delivery is that the rate of regional blood inflow to the inner and outer medulla is lower than that to the renal cortex. ${ }^{106}$ Furthermore, the acute angle between the interlobular artery and the afferent arterioles supplying juxtamedullary glomeruli causes the capillary hematocrit in the medulla to be dramatically lower than that in the cortex. This is due to a phenomenon termed plasma skimming, in which erythrocytes that are primarily in the center of vessels continue to flow in the interlobular artery towards the superficial cortex, while the plasma in the periphery of the capillary is captured by the juxtamedullary afferent arterioles and ultimately flows into vasa recta. ${ }^{107,108}$ In addition to the architecture of the kidney limiting oxygenation, kidney tubules are characterized by a limited ability to generate energy under anaerobic conditions, causing oxygen to be consumed rapidly in the metabolic processes involved in active salt reabsorption. Consequently, the twin constrains of low oxygen supply dictated by renal structure and high oxygen demand dictated by renal function conspire to make the kidney particularly vulnerable to physiologic and environmental stresses that cause ischemia.

\section{Anemia}

Anemia has long been known to be an independent physiologic risk factor for the development of CKD. ${ }^{6-9}$ The obvious way in which anemia impacts unfavorably on renal oxygenation is that it is characterized by fewer erythrocytes in the circulation and consequently blood with a reduced oxygen-carrying capacity. The Epo-TAg ${ }^{\mathrm{h}}$ transgenic mouse has severe anemia caused by targeted disruption of the gene encoding erythropoietin (EPO). ${ }^{109}$ Consistent with the connection of anemia to the development of CKD, the Epo-TAg ${ }^{\mathrm{h}}$ mouse mimics CKD pathology by exhibiting renal hypoxia., ${ }^{9109}$ In addition, EPO administration has been shown not only to correct anemia but also protect against ischemia-induced kidney damage. ${ }^{110-112}$ This protective effect could clearly stem from enhanced delivery of oxygen by an increased mass of erythrocytes. However, the renoprotective ability of EPO also appears to be due to mechanisms independent of its ability to increase red blood cell production. ${ }^{113,114}$ Here EPO binds a heterodimer on the surface of renal cells composed of the EPO receptor and CD131. ${ }^{115}$ This binding then elicits a cascade of intracellular signaling events involving the dephosphorylation of p38 mitogen-activated protein kinase and the phosphorylation of Janus kinase 2, signal transducer and activator of transcription 5, serine/threonine protein kinase B, serum and glucocorticoid-regulated kinase 1 and glycogen synthase kinase $3 \beta .{ }^{113,114,116,117}$ The net result of these events is that apoptosis is inhibited through reduced expression of proapoptopic nuclear factor- $\kappa \mathrm{B}$ and Bcl-2-like protein 4 and increased expression of the anti-apoptopic molecules B-cell lymphoma 2, B-cell lymphoma extra-large and X-linked inhibitor of apoptosis protein. ${ }^{113,114,118-122}$ In addition, EPO effects renoprotection by ameliorating oxidative stress through increased expression of glutathione peroxidase, superoxide dismutase and endothelial nitric oxide synthase. ${ }^{113,123}$ EPO also down-regulates the ability of renal tissue to produce increased levels of intercellular adhesion molecule 1 and proinflammatory cytokines and chemokines in response to ischemia. As a consequence, renal tissue is less susceptible to attack by neutrophils and macrophages. ${ }^{121,122}$

\section{Hyperglycemia}

Diabetic patients with poorly controlled blood glucose levels are at high risk of developing renal dysfunction, and diabetesinduced renal complications are a major cause of morbidity and mortality. ${ }^{124,125}$ Diabetes is associated with decreased renal oxygen tension. ${ }^{11}$ Several mechanisms have been implicated in driving this process. Hyperglycemia induces the formation of reactive oxygen species by renal mitochondria, nicotinamide adenine dinucleotide phosphate oxidase, and uncoupled nitric oxide synthase..$^{10}$ The reactive oxygen species superoxide then directly interacts with nitric oxide, forming peroxynitrite and, thus, reducing nitric oxide bioavailability. A process independent of reactive oxygen species decreases L-arginine, further reducing the bioavailability of nitric oxide. ${ }^{11}$ Reduced nitric oxide and increased reactive oxygen species independently both lead to increased oxygen consumption. ${ }^{11}$ 
In addition, reduced nitric oxide causes vasoconstriction that limits renal blood perfusion and, therefore, oxygen delivery. ${ }^{12}$ Hyperglycemia also limits renal perfusion by narrowing the diameter of arterioles within the glomerulus through inducing extracellular collagen accumulation and the proliferation of mesangial, distal tubular epithelial, and vascular smooth muscle cells. ${ }^{126-129}$ The molecular mechanism by which this is achieved involves hyperglycemia producing sustained activation of protein kinase $\mathrm{C}$ and nuclear factor kappa-lightchain-enhancer of activated B cells that in turn stimulates the release of osteopontin. ${ }^{129-134}$ This growth factor then binds and activates its $\beta 3$-integrin receptor that signals to induce the synthesis of both DNA and collagen. ${ }^{129,135}$ An additional consequence of hyperglycemia inducing protein kinase $\mathrm{C}$ is that this increases expression of intercellular adhesion molecule 1 by mesangial cells, thus promoting glomerular damage effected by infiltrating mononuclear cells. ${ }^{133}$ The link between hyperglycemia, renal hypoxia, and the development of CKD is further evidenced by analysis of the obese $\mathrm{db} / \mathrm{db}$ mouse model of diabetic nephropathy. ${ }^{136}$ This model exhibits hyperglycemia, increased production of reactive oxygen species, loss of capillaries, arteriolar constriction, and a decrease in resting and maximum blood flow. ${ }^{136-139}$ Consistent with these characteristics causing kidney damage through hypoxia, the $\mathrm{db} / \mathrm{db}$ mouse shows increased glomerular expression of hypoxia-inducible factor 1 (HIF-1) and other genes involved in oxidative stress. ${ }^{140}$

\section{Hypertension}

The hallmark of systemic hypertension is chronic induction of multiple vasoconstrictors including the renin-angiotensinaldosterone system, constrictor prostaglandins and endothelin. ${ }^{141-143}$ Constriction of blood vessels limits blood flow and consequently reduces oxygen delivery to the kidney. ${ }^{14-17}$ In addition, hypertension leads the kidney to consume approximately twice as much oxygen as normal to transport a given amount of sodium. ${ }^{16}$ Consequently, the combination of reduced oxygen delivery caused by vasoconstriction and increased oxygen demand caused by aberrant metabolism results in lower renal oxygenation. Specifically, the oxygen tension of the kidney cortex and medulla has been shown to be approximately $10 \mathrm{~mm} \mathrm{Hg}$ lower than normal in spontaneously hypertensive rats and other models of hypertension as well as in hypertensive patients. ${ }^{15,89,144-146}$ The role of hypertension in the progression of CKD was first described in 1914 by Volhard and Fahr. ${ }^{13}$ Subsequently, it was appreciated that hypertension predisposes to kidney failure by inducing renal hypoxia. ${ }^{147,148}$ The detrimental effects of hypoxia are exacerbated by hypertension also inducing kidney tissue to generate elevated levels of reactive oxygen species such as superoxide, hydrogen peroxide, peroxynitrite, and hydroxyl radicals. ${ }^{149}$ These species are formed by elevated intrarenal angiotensin II binding type 1 angiotensin II receptors that then transduce signals to activate the pro-oxidant enzyme nicotinamide adenine dinucleotide phosphate-oxidase..$^{150,151}$ The generation of reactive oxygen species is further augmented by decreased expression of the anti-oxidant enzymes superoxide dismutase 1 and 3 and isoforms of nitric oxide synthase. ${ }^{151}$ The reactive oxygen produced as a consequence of hypertension acts in the same way as that generated during hyperglycemia to drive renal hypoxia. That renal hypoxia caused by hypertension directly contributes to the development of CKD is demonstrated by angiotensin receptor blockers, angiotensinconverting enzymes, and the anti-oxidant tempol all normalizing renal oxygenation and function in hypertensive rats. ${ }^{15,16,148,152-154}$

\section{Hypercholesterolemia}

High cholesterol levels have been shown to correlate with reduced renal oxygenation and increased kidney damage in response to ischemia. ${ }^{155-157}$ One mechanism by which cholesterol likely drives these processes is through its role in determining the physical properties of the cell surface. Cholesterol constitutes the non-polar, hydrophobic lipid of the enveloping layer of the erythrocyte membrane. This cholesterol is in equilibrium with the concentration of plasma cholesterol. Consequently, as the concentration of plasma cholesterol increases so does the cholesterol content of the erythrocyte membrane. Under such circumstances the fluidity of the membrane decreases and the lipid shell stiffens. This produces a greater barrier to oxygen diffusion that both delays oxygen entry into the erythrocyte during saturation and delays oxygen release during desaturation. ${ }^{18-20}$ Indeed, the percentage change in blood oxygen diffusion has been found to be inversely proportional to plasma cholesterol concentration. ${ }^{18}$ Consequently, cholesterol contributes to renal hypoxia by reducing the erythrocyte capacity to both load and release oxygen. Hypercholesterolemia also results in lipid deposition in kidney tissue. ${ }^{158}$ Thus, oxygen delivery by diffusion is again compromised. Furthermore, lipid deposition in renal arteries increases their stiffness and reduces their ability to dilate and deliver an augmented blood flow when oxygen tensions are low. ${ }^{159,160}$ Besides contributing to renal hypoxia through its physical properties, cholesterol also likely contributes through its metabolism. Resistance to hypoxia-induced kidney damage has been shown to be mediated by increased de novo synthesis of esterified cholesterol and the cholesterol transport protein $18 \mathrm{KDa}$ translocator protein. ${ }^{161-163}$ However, chronically high cholesterol levels repress expression of both these molecules, so compromising cytoprotection during ischemia. ${ }^{164-167}$

\section{Cigarette Smoking}

Both active and passive cigarette smoking have been found to be independent risk factors for the de novo development of CKD in healthy subjects. ${ }^{168-176}$ Cigarette smoking is also a major risk factor for the initial development or worsening of preexisting CKD in patients with human immunodeficiency virus infection, chronic obstructive pulmonary disease, diabetes, diabetic nephropathy, hypertension, autosomal polycystic kidney disease, primary glomerulopathies, lupus nephritis, and those who are obese or who have undergone a lung transplant. ${ }^{177-187}$ In addition, smoking by either the donor 
or recipient has been shown to adversely influence the function and survival of transplanted kidneys and overall patient survival. ${ }^{170,171,188,189}$ Allograft survival and function both worsen with increasing pack-years smoked. The number of cigarettes smoked correlates directly with the severity of renal dysfunction and the likelihood that either CKD will develop or a kidney allograft will fail. ${ }^{24,168,170,181,190}$ Conversely, smoking cessation reduces the risk of developing CKD and is of benefit to patients where the condition pre-exists. ${ }^{176,190,191}$ Mainstream cigarette smoke has been said to contain 4,000 or more constituents. ${ }^{22-24,192}$ Some of these, like cadmium and lead, are directly nephrotoxic. ${ }^{193,194}$ Other constituents like tar, carbon monoxide, nicotine, and reactive oxygen species, effect kidney damage by compromising oxygenation. The accumulation of tar in the lung results in a physical barrier that impairs gas exchange within alveoli. Consequently, carbon dioxide is less effectively released and oxygen less effectively acquired by erythrocytes. In addition, tar further reduces oxygen availability to erythrocytes by inducing inflammatory reactions that demand increased oxygen consumption. ${ }^{22}$ The carbon monoxide in cigarette smoke reversibly binds various heme-containing proteins within the body. These proteins include hemoglobin, myoglobin, cytochrome $\mathrm{P} 450$, and cytochrome oxidase that are responsible for oxygen transport. Since the bond formed between heme and carbon monoxide is less dissociable than the hemeoxygen bond, severe disruption of normal oxygen transport can occur. ${ }^{26,27}$ The nicotine of cigarette smoke induces degradation of nitric oxide and stimulates parasympathetic nerves. Both these processes constrict the vasculature, so limiting blood flow and oxygen delivery to the kidney. ${ }^{21,25}$ In addition, nicotine binds a range of nicotinic acetylcholine receptors expressed by mesangial, endothelial, vascular smooth muscle, and renal proximal and distal tubule cells. ${ }^{195-198}$ These receptors are expressed under normoxic conditions but are induced by both transient and chronic hypoxia. ${ }^{199,200}$ Upon nicotine binding, receptors mediate activation of protein kinase $\mathrm{C}$ that in turn activates nicotinamide adenine dinucleotide phosphate-oxidase to produce reactive oxygen species. ${ }^{195,196,201-204}$ Stable compounds within cigarette smoke, such as acrolein, also induce endothelial production of reactive oxygen species through activation of nicotinamide adenine dinucleotide phosphate-oxidase. ${ }^{205}$ These oxygen species then act in the same way as those generated through hypertension and hyperglycemia to drive renal hypoxia and kidney damage. In addition, the reactive oxygen species produced in response to nicotine also induces mesangial cell proliferation and extracellular matrix deposition through pathways that involve increased expression of cyclooxygenase 2-derived prostaglandins and increased phosphorylation of extracellular signal-regulated protein kinases 1 and 2, c-Jun $\mathrm{N}$-terminal kinases, activator protein 1, and protein kinase B. ${ }^{195,196,204,206-210}$ This aberrant proliferation and deposition mirrors the protein kinase $\mathrm{C}$ dependent processes by which hyperglycemia constricts glomerular arterioles to limit blood flow and, hence, oxygen delivery to the kidney. In an additional mirror of hyperglycemia, nicotine also promotes hypoxia by facilitating oxygen-consuming inflammation. This occurs through increased expression of unphosphorylated signal transducer and activator of transcription 3 that induces renal proximal tubule cells to secrete the pro-inflammatory cytokine transforming growth factor $\beta 1$ and the proinflammatory chemokine monocyte chemotactic protein $1 .{ }^{210}$ Finally, with a higher daily number of cigarettes smoked or a longer duration of smoking the risk of developing hypertension increases. ${ }^{211-213}$ Consequently, it is logical to assume that beyond its own specific mechanisms of inducing hypoxiamediated CDK, cigarette smoking also utilizes those manifest in hypertension.

\section{Air Pollution}

The ready access of the lungs and blood stream makes them unusually susceptible to the deleterious effects of airborne pollutants. ${ }^{28,29}$ Carbon monoxide breathed passively from second-hand smoke or atmospheric pollution can produce hypoxic affects similar to those produced by active cigarette smoking. ${ }^{27}$ Nitrogen dioxide and sulphur dioxide may render hemoglobin useless for oxygen transport by driving its conversion to methemoglobin or sulfhemoglobin. ${ }^{29}$ Lead and arsine can damage the erythrocyte membrane resulting in anemia. ${ }^{29}$ Ozone is formed for the most part by the interaction between solar radiation and nitric oxides, carbon monoxide, and volatile hydrocarbons. These are the primary pollutants of traffic exhaust fumes. Ozone causes acute arterial vasoconstriction, reducing blood flow and limiting oxygen delivery. ${ }^{30}$ Ultrafine particles of aerodynamic diameter $0.1 \mu \mathrm{M}$ are emitted by diesel engines and can pass directly into the blood circulation, limiting oxygen delivery by inducing vasoconstriction, vascular inflammation, and increasing blood viscosity. ${ }^{30-32}$ Fine particles of $2.5 \mu \mathrm{M}$ emitted by diesels accumulate within the pulmonary alveoli and cause an inflammatory reaction of the lung that is related both to their physical parameters and the oxidative stress generated by the organic and metallic compounds adsorbed onto their surface. ${ }^{33}$ These compounds trigger the local production by macrophages and activated alveolar cells of inflammatory cytokines such as interleukin 6 and tumor necrosis factor $\alpha$ and the potent vasoconstrictor endothelin $1 .^{30,32,33}$ As with diesel particles and cigarette tar, the dust produced from coal, silica, wheat, flax, and rice and the fibers originating from cotton, silk, fiberglass, and asbestos can build up in the lungs, limiting gas exchange and inducing oxygen-consuming inflammation. ${ }^{34-40}$ Furthermore, dusts originating from agricultural products such as flax, cotton, rice, wheat, and wood are loaded with gram-negative bacterial endotoxin. Exposure to such endotoxin elicits chronic inflammation within the lungs that drives a long-term decline in their function. ${ }^{36-40}$ In summary, air pollution can reduce renal oxygenation through a host of mechanisms. These include the induction of oxygenconsuming inflammation, that reduces the ability of the lungs to effect gas exchange, and anemia, vasoconstriction, and hemoglobin conversion that reduces the oxygen delivery capacity of the blood stream. That air pollution does indeed compromise kidney function is supported by the finding that 
glomerular filtration is compromised by breathing heavy metals from copper smelters and by living in close proximity to major roadways. ${ }^{41,42}$ In addition, rats exposed to either the asbestos group member amosite or to passive smoking develop significant glomerulosclerosis and tubulinterstitial fibrosis, and occupational exposure to silica, fiberglass, or solvents has been linked to an increased risk of developing ESRD. ${ }^{35,214}$

\section{Atherosclerosis}

Approximately six million Americans have combined atherosclerosis and kidney disease. ${ }^{47}$ The development of atherosclerosis stems from multiple interactions among injurious stimuli and the healing or reparative responses of the arterial wall. ${ }^{48}$ After endothelial injury, direct cell-cell interaction and the secretion of chemotactic and growth factors induce recruitment of monocytes to subintimal regions, smooth muscle proliferation and increased synthesis of matrix proteins. The recruited monocytes differentiate into macrophages, accumulate lipid and ultimately become foam cells. Together with accompanying T-lymphocytes, these changes represent the fatty streak, an early histopathological change indicating atherosclerosis. Progression of this atherosclerotic lesion is marked by the accumulation of alternating layers of smooth muscle cells and lipid-laden macrophages. The advanced lesions of atherosclerosis compromise the lumen diameter, reducing the blood flow in arteries and thus limiting kidney oxygenation. ${ }^{44-46,49-52}$ In the early stages of atherosclerotic renal artery stenosis progressive decreases in blood flow are accompanied by compensatory changes in arteriovenous shunting, and decreases in glomerular filtration rate and tubular reabsorption of sodium, that either increase oxygen availability or reduce its consumption. Within the whole kidney these adaptive mechanisms appear to maintain appropriate oxygenation. ${ }^{215}$ However, direct measurements of intra-renal tissue oxygenation demonstrate the induction of regional hypoxia in the cortex, but especially the medulla. ${ }^{216-218}$ This heterogenous pattern of intra-renal hypoxia likely results from inherent differences in the physiology and vasculature of the renal cortex and medulla. ${ }^{219}$ These cause stenosis to induce localized microvascular dysfunction and rarefaction, inflammation, oxidative stress, and/or fibrosis. ${ }^{219-223}$ While reductions in oxygen consumption can maintain whole-kidney oxygenation when renal artery stenosis is moderate, this compensatory mechanism becomes overwhelmed when vascular occlusion reaches between $70 \%$ and $80 \%$. Under these circumstances cortical hypoxia is overt, leading to activation of the reninangiotensin-aldosterone system, loss of kidney function, rarefaction of small renal vessels, kidney fibrosis, atrophy, and end stage kidney disease designated "ischemic nephropathy". ${ }^{221,223,224-228}$ The connection between atherosclerosis-driven renal hypoxia and CKD is underscored by the finding that the preservation of microvascular architecture by intra-renal administration of vascular endothelial growth factor decreases renal fibrosis and maintains renal hemodynamics and function in an experimental model of renal artery stenosis.224 In addition, when femoropopliteal angioplasty restores the lumen diameter in patients with generalized atherosclerosis, the incidence of renal disease is dramatically reduced. ${ }^{43}$ Furthermore, several clinical trials have validated renal angioplasty and stenting in treating renal artery stenosis, especially in high-risk patients with recurrent flash pulmonary edema. ${ }^{229-231}$ Controversy exists as to whether kidney reoxygenation through this surgery is superior to that induced by medical therapy. Nevertheless, the goal of both strategies is to correct renal hypoxia. A goal reinforced by the practice guidelines of the American Heart Association and the American College of Cardiology Foundation that state the preferred treatment for hemodynamically significant renal artery stenosis is improved kidney oxygenation. ${ }^{49}$

\section{Repeated Episodes of Acute Kidney Injury}

Acute kidney injury (AKI) is the generic term for an abrupt and sustained decrease in renal function that can be reversible if treated promptly and appropriately. ${ }^{53}$ Most major causes of AKI produce conditions of hypoxia within the kidney. These include sepsis that induces renal vasoconstriction through the release of endothelin and the use of radiocontrast imaging dyes that increase oxygen consumption for solute reabsorption and reduce regional inner medullary blood flow. ${ }^{54-61}$ More generalized reductions in blood flow represent another major cause of AKI. These can result from hemorrhage, decompensated liver cirrhosis, treatment with non-steroidal anti-inflammatory drugs, congestive heart failure, and renal artery occlusion or stenosis. ${ }^{53}$ In addition, many forms of surgery where blood flow is inadvertently or deliberately reduced carry an inherent risk for the development of AKI. ${ }^{62-70}$ Inadvertent surgical reductions in blood flow can be caused by voluminous blood loss such as often occurs during major hepatic resections. ${ }^{64,69}$ Deliberate blood flow reduction is caused by the clamping of major blood vessels such as occurs during organ transplantation, cardiopulmonary bypass, and thoracoabdominal aneurysm surgery. ${ }^{63,65,66,70}$ Meta-analysis, epidemiological, and clinical follow-up studies have all shown a strong correlation between AKI episodes and subsequent development of CKD. ${ }^{232-236}$ This correlation is observed even in patients who regained normal renal function after AKI ${ }^{237}$ Strikingly, both the severity and the number of AKI episodes are predictive of CKD development. ${ }^{238,239}$ These data, along with animal studies, have established a causal relationship between AKI and the subsequent development of CKD. ${ }^{240-242}$ Induction of AKI in animals by ischemia, radiocontrast agents, cisplatin, or rhabdomyolysis all induce oxygen tensions below $10 \mathrm{~mm} \mathrm{Hg}$ deep within kidney tissue. ${ }^{95,243-247}$ In addition, impaired renal oxygenation has also been observed in human AKI. ${ }^{248}$ Importantly, renal hypoxia is found not only during the acute phase of AKI but also up to 5 weeks later, after the recovery phase. ${ }^{243,249,250}$ This sustained hypoxia results in the kidney down-regulating pro-angiogenic isoform 164 and up-regulating dys-angiogenic isoforms 120 and 188 of vascular endothelial growth factor A (VEGF-A) ${ }^{251,252}$ As a consequence, the vascular architecture 
of the kidney fails to be maintained with reductions in capillary number as well as individual capillary caliber and area. ${ }^{252-255}$ Thus, the initial hypoxia insult caused by an episode of AKI is consolidated by subsequent capillary rarefaction that reduces oxygen delivery. This chronic hypoxia then induces a slew of pathological processes in tubular epithelial cells including apoptosis, the prevention of redifferentiation after regeneration and conversion to myofibrolasts. ${ }^{256-260}$ Hypoxia also induces monocytes to express the $\beta 2$ integrin family of adhesion molecules and kidney cells to express vascular cell adhesion molecule 1 and intracellular adhesion molecule 1 as well as the monocyte chemo-attractants $\mathrm{C}-\mathrm{C}$ motif ligand 2 and $\mathrm{C}-\mathrm{X} 3-\mathrm{C}$ motif ligand 1.252,261-264 These hypoxia-dependent changes in gene expression appear mediated in part by chromatin-remodeling, histone modification and the transcription factors HIF-1 and purine-rich binding protein alpha (Pur $\alpha$ ). ${ }^{261-265}$ Therefore, by inducing pro-inflammatory adhesion molecules and chemokines, hypoxia causes the accumulation of macrophages in the kidney that produce profibrotic cytokines such as

Table 1. Targeting renal hypoxia: current and potential future treatments for chronic kidney disease

\begin{tabular}{l} 
Hypoxia pathology \\
\hline Systemic hypo-oxygenation
\end{tabular}
Therapeutic strategy

Erythropoiesis induction ${ }^{110-112}$

Continuous positive airway pressure (CPAP) $)^{81,83,87,377}$

Hyperbaric oxygen therapy (HBOT) $)^{378}$

Vasoconstriction

Microvascular rarefaction

Oxidative stress

Leukocyte recruitment

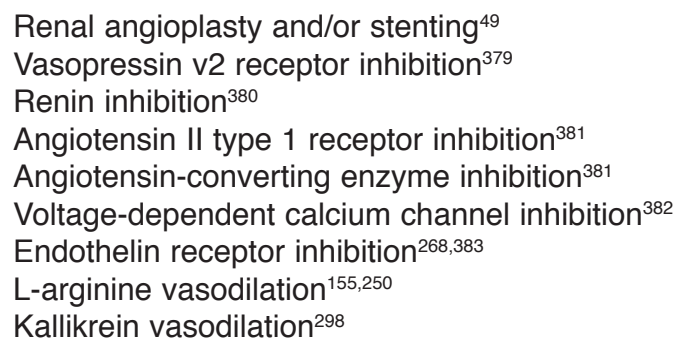

Platelet-derived growth factor receptor $\beta$ inhibition ${ }^{252}$

Vascular endothelial growth factor receptor 2 inhibition ${ }^{252}$

Vascular endothelial growth factor 121 administration ${ }^{400}$

Angiopoietin 1 administration 401

3-hydroxy-3-methyl-glutaryl-CoA reductase inhibition 223

MicroRNA 93 vascular endothelial growth factor inhibitor inhibition ${ }^{402}$

Bendavia mitochondria protection ${ }^{403}$

Pirfenidone mitochondrial protection ${ }^{404}$

Mammalian target of rapamycin inhibition ${ }^{405}$

Antioxidant administration ${ }^{406}$

Nuclear factor erythroid 2-related factor 2 mild induction ${ }^{407}$

Uncoupling protein 2 inhibition ${ }^{408}$

Hemeoxygenase 1 induction 409

Semicarbazide-sensitive amine oxidase inhibition ${ }^{410}$

AMP-activated protein kinase activation ${ }^{411}$

Nitric oxide induction ${ }^{412}$

Phosphodiesterase inhibition ${ }^{413}$

Soluble epoxide hydrolase inhibition ${ }^{414}$

Nicotinamide adenine dinucleotide phosphate oxidase inhibition ${ }^{415}$

Transforming growth factor $\beta$ type I receptor inhibition ${ }^{416}$

Cyclooxygenase 2 inhibition ${ }^{417}$

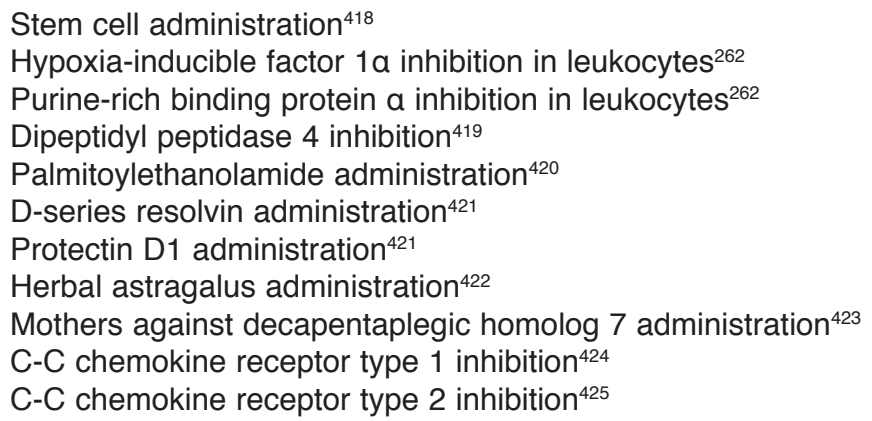

Stem cell administration ${ }^{418}$

Hypoxia-inducible factor $1 a$ inhibition in leukocytes ${ }^{262}$

Purine-rich binding protein a inhibition in leukocytes ${ }^{262}$

Dipeptidyl peptidase 4 inhibition ${ }^{419}$

Palmitoylethanolamide administration ${ }^{420}$

D-series resolvin administration ${ }^{421}$

Protectin D1 administration ${ }^{421}$

Herbal astragalus administration ${ }^{422}$

Mothers against decapentaplegic homolog 7 administration ${ }^{423}$

$\mathrm{C}-\mathrm{C}$ chemokine receptor type 1 inhibition ${ }^{424}$

$\mathrm{C}-\mathrm{C}$ chemokine receptor type 2 inhibition ${ }^{425}$ 
Table 1 Continued.

\begin{tabular}{|c|c|}
\hline Fibrosis & 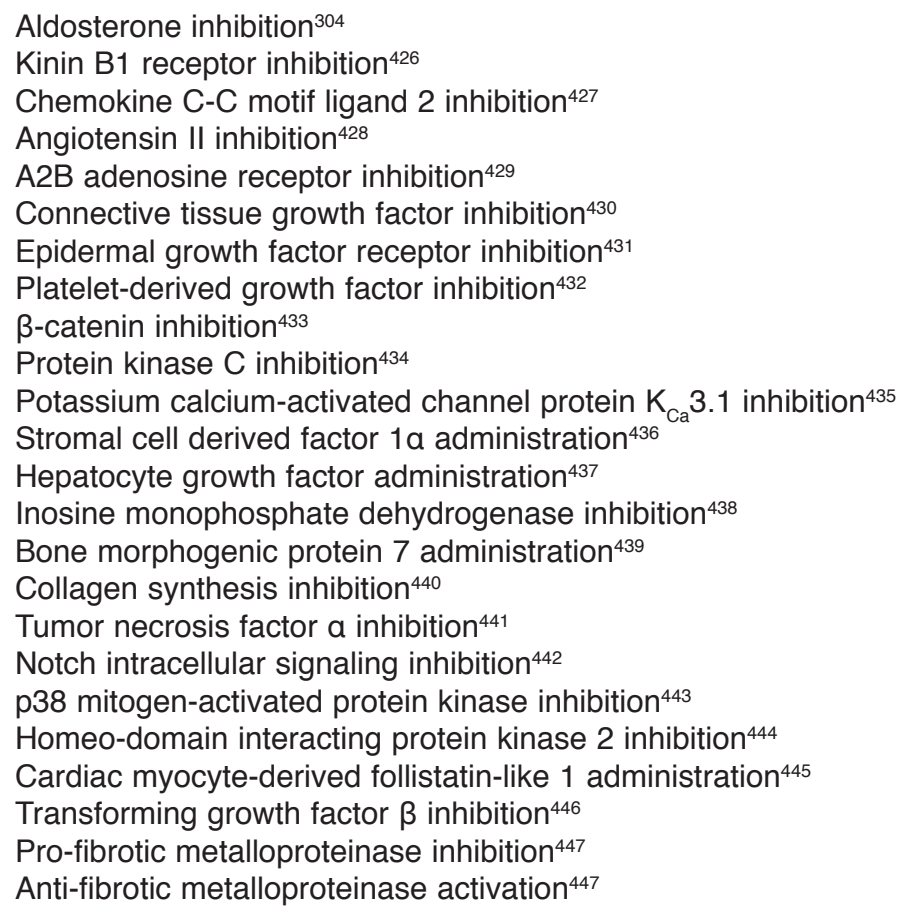 \\
\hline $\begin{array}{l}\text { Destabilization of renal } \\
\text { hypoxia-inducible factor }\end{array}$ & $\begin{array}{l}\text { Remote ischemic pre-conditioning } \\
\text { Prolyl hydroxylase inhibition } \\
\text { von Hippel-Lindau protein inhibition } \\
\text { von }\end{array}$ \\
\hline
\end{tabular}

transforming growth factor $\beta$ and activate renal fibrobalsts. ${ }^{100,101,253}$ Hypoxia also activates fibroblasts directly to increase extracellular matrix deposition by increasing production of collagen and tissue inhibitor of metalloproteinase I and decreasing expression of collagenase. ${ }^{266}$ This activation of fibroblasts, along with the recruitment of inflammatory cells and the damage done to tubular epithelial cells, all lead to tubulointerstitial fibrosis. This fibrosis, in turn, aggravates hypoxia by increasing the distance between capillaries and tubular epithelial cells, leading to reduced oxygen diffusion efficiency. ${ }^{97}$ Consequently, hypoxia and tubulointerstitial fibrosis form a pathologic cycle that results in the progression of CKD (figure 1). ${ }^{242}$ The cycle is exacerbated by hypoxiainducing gene-activating histone modifications that up-regulate expression of endothelin 1, thus, reducing oxygen delivery to the kidney by vasoconstriction. ${ }^{267,268}$

\section{Sleep Apnea}

Sleep apnea occurs in approximately $60 \%$ of patients with CKD. ${ }^{74-76}$ This prevalence is much higher than the $20 \%$ rate found in the general population. ${ }^{269}$ There are two main types of sleep apnea, termed obstructive and central. ${ }^{71-73}$ Obstructive sleep apnea is characterized by abnormal collapse of the pharyngeal airway, while central sleep apnea is characterized by a chronic lack of drive to breath. Sleep apneas are very common, affecting about $16 \%$ of men and $5 \%$ of women between 30 and 65 years-of-age. Cross-sectional cohort studies have demonstrated a significant direct association between the severity of sleep apnea and the severity of renal dysfunction. ${ }^{270-276}$ In addition, cohort studies of the longitudinal relationship between sleep apnea and kidney function show that apnea is independently associated with an increased risk of accelerated loss of kidney function. ${ }^{277,278}$ Conversely, as kidney function declines, the prevalence of sleep apnea and nocturnal hypoxia increases. ${ }^{272}$ Furthermore, aggressive dialysis has been found to improve obstructive sleep apnea. These findings have led to the contention that sleep apnea and CKD have a bidirectional relationship with both diseases being a risk factor for the other. ${ }^{279} \mathrm{CKD}$ may lead to sleep apnea by autonomic nerve damage, effected by generalized uremic neuropathy, interfering with baroreceptor activity, pharyngeal narrowing due to fluid overload, and accumulation of uremic toxins. ${ }^{279-284}$ Sleep apnea likely causes CKD through numerous mechanisms that promote renal hypoxia. ${ }^{285,286}$ The most obvious mechanism is that apnea causes insufficient or absent ventilation, compromised gas exchange, and, thus, intermittent nocturnal hypoxia. ${ }^{77-81,83-86}$ Long-term exposure to these recurrent episodes of hypoxiareoxygenation activate nicotinamide adenine dinucleotide phosphate-oxidase 2 that consumes oxygen through its generation of reactive oxygen species. ${ }^{287-291}$ Tissue damage effected by these species is augmented by intermittent hypoxia reducing renal expression of antioxidants. ${ }^{292}$ In addition, intermittent hypoxia induces the sympathetic nervous system to increase vascular resistance, downregulates expression of the kallikrein-kallistatin vasodilator 
pathway, and activates the renal renin-angiotensin-aldosterone system to cause vasoconstriction. ${ }^{293-299}$ Together these processes conspire to produce renal fibrosis and sustained hypertension and their associated means of reducing renal oxygenation (figure 1)..$^{82,300-304}$ Oxygenation is further compromised by nocturnal hypoxia altering parasympathetic control of heart rate and inducing left ventricular hypertrophy. ${ }^{305,306} \mathrm{An}$ additional consequence of sleep apnea is that it activates nuclear factor $\kappa \mathrm{B}$, initiating a cascade of events that include increased production of tumor necrosis factor $\alpha$, interleukin 6 , interleukin 8 , interleukin 18, C-reactive protein, and C-C motif ligand 2. ${ }^{307-309}$ The resulting systemic inflammation, together with apnea-induced reactive oxygen species, hypertension, and platelet aggregability, drives the development of atherosclerosis and its mechanisms of generating renal hypoxia (figure 1). Indeed, chronic intermittent hypoxia linked with a high-fat diet has been shown to cause the de novo generation of atherosclerotic plaques. $^{310}$ The profound consequences of atherosclerosis induced by sleep apnea are evident by it being an independent risk factor for cardiovascular mortality both in the general population and in patients with ESRD. ${ }^{76,84,311-316}$ Renal

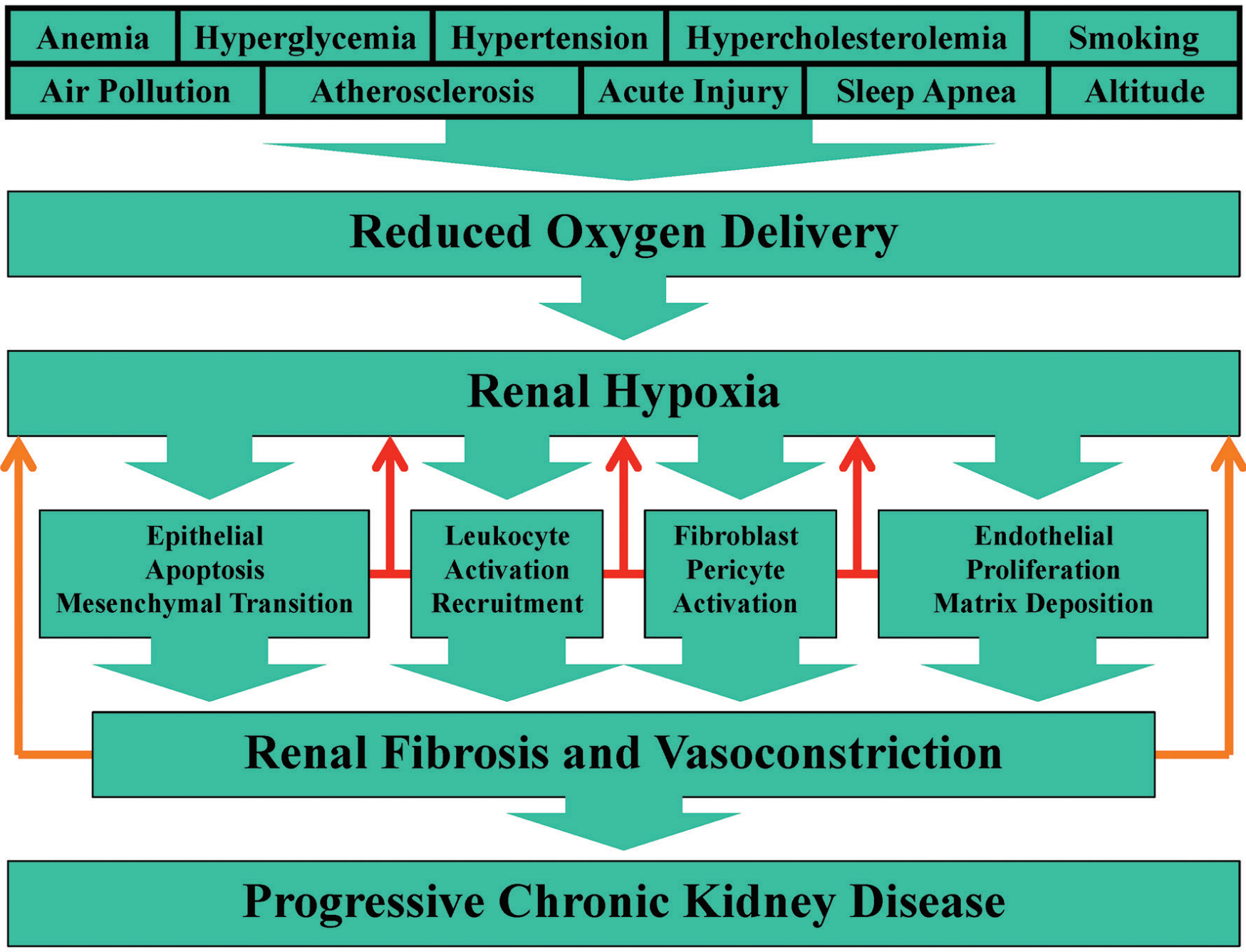

Figure 1. The hypoxia cycle driving chronic kidney disease. A constellation of environmental, behavioral, and physiologic risk factors reduce systemic oxygenation. In many cases these conditions exacerbate one another. Due to its vascular architecture and physiologic function, the kidney is particularly vulnerable to lowered oxygen tensions. This vulnerability is counteracted by defense mechanisms centered around activation of hypoxiainducible factor. While these defense mechanisms are effective when periods of hypoxia are brief, they are overwhelmed when risk factors cause prolonged hypoxia. Under these circumstances a range of pathological cellular processes are activated, all of which aggravate renal hypoxia by metabolically consuming oxygen (red arrows). In addition, these processes cause renal fibrosis and vasoconstriction further aggravating hypoxia by limiting oxygen diffusion and reducing erythrocyte access (orange arrows). The net result is that a self-reinforcing cycle is established in which hypoxia causes cellular pathologies that themselves compromise renal oxygenation. The inevitable consequence of this cycle is progressive chronic kidney disease. 
oxygenation is significantly improved by the treatment of sleep apnea with continuous positive airway pressure. ${ }^{81}$ This treatment also ameliorates glomerular hyperfiltration, improves endothelial function and survival, reduces the production of reactive oxygen species, C-reactive protein and interleukin 6 , increases vasodilator levels, and decreases the levels of vasoconstrictors. ${ }^{81,83,87,317-322}$ That re-oxygenation has such a dramatic beneficial influence on renal function further underscores the intimate connection between renal hypoxia and the pathogenesis of CKD.

\section{The Hypoxia Death Cycle}

Environmental, behavioral, and pathophysiological risk factors each, in their own way, reduce systemic oxygenation or the specific oxygenation of the kidney. Many of these risk factors are inter-related, with one being a risk factor for the development of another. Consequently, a perfect storm of conditions can develop that pushes the pre-existing condition of low oxygen tension in the kidney into the realm of hypoxia (figure 1). When this occurs, renal cells initially respond with protective mechanisms that center around the phosphorylation of extracellular signal-regulated protein kinases 1 and 2 and the resulting stabilization of both HIF-1 $\alpha$ and HIF$2 \alpha .^{94-96,292,323-325}$ These protective mechanisms include the up-regulation of pro-angiogenic factors such as isoform 164 of VEGF-A that protect against capillary rarefaction, and increased expression of matrix metalloproteinases that effect repair and protect against fibrosis by degrading extracellular matrix. ${ }^{326,327}$ In addition, short-term exposure to hypoxia leads to increased renal expression of antioxidants such as nuclear factor erythroid 2-related factor 2, hemeoxygenase 1, and metallothionein I that protect against fibrosis and inflammation induced by reactive oxygen species. ${ }^{94,292,328-330}$ However, when hypoxia is prolonged, there is an up-regulation of natural antisense HIF-1 $\alpha$ that decreases HIF- $1 \alpha$ expression by destabilizing its mRNA. ${ }^{331}$ In addition, increasing levels of reactive oxygen species target the $\mathrm{HIF}-1 \alpha$ protein for degradation through the ubiquitin-proteosome system. ${ }^{332,333}$ The expression of HIF- $2 \alpha$ is unaffected by prolonged hypoxia, thus, there is a shift in the quanlitative nature of HIF away from subunit $1 \alpha$ and towards subunit $2 \alpha .^{331}$ This shift in HIF expression likely underlies the observation that under conditions of prolonged hypoxia the initial protective mechanisms of the kidney either fail to be engaged or are down-regulated. ${ }^{292,334,335}$ Thus, the expression of proangiogenic factors such as VEGF-A isoform 164 is repressed, and the expression of dys-angiogenic factors such as VEGF-A isoforms 120 and 188 is increased, causing capillary rarefaction. 221,223,251,252 Fibrosis is driven by decreased expression of metalloproteinases and increased expression of their inhibitors and extracellular matrix proteins. ${ }^{336,337}$ Expression of antioxidants either fails to be induced or is decreased, allowing increased expression of reactive oxygen species to affect tubulointerstitial fibrosis through necrosis, apoptosis, activation of interstitial fibroblasts and pericytes, proliferation of endothelial cells, and epithelial-mesenchyme transition (figure 1). ${ }^{109-113,259,292,336-343}$ In addition, prolonged hypoxia causes renal endothelium to produce proinflammatory adhesion molecules, cytokines, and chemokines that activate macrophages already resident within the kidney and also recruit additional inflammatory cells from the circulation. $^{344}$ Activated macrophages exacerbate the inflammatory process by producing additional cytokines such as tumor necrosis factor $1 \alpha$ and interleukin $6 .{ }^{345}$ Furthermore, they destroy renal tissue by phagocytosis and promote fibrosis by producing pro-fibrotic cytokines, such as transforming growth factor $\beta 1 .{ }^{346-348}$ The net result of prolonged hypoxia is that a vicious pathological cycle is initiated in which fibroblast and inflammatory cell activation combine with apoptosis, endothelial proliferation, and epithelial-mesenchymal transition to cause tubulointerstitial fibrosis. This fibrosis then further drives renal hypoxia by limiting oxygen diffusion. In addition, prolonged hypoxia also induces the renal cortex to up-regulate expression of the potent vasoconstrictor endothelin 1 and its type A receptor. ${ }^{268}$ Consequently, the kidney is further "suffocated" to CKD (Figure 1). ${ }^{97}$

\section{A New Hypoxia Paradigm}

The recruitment of inflammatory cells into the hypoxic kidney is driven by increased inter-cellular adhesion. This is totally dependent upon increased function of adhesion molecules expressed both on the surface of inflammatory cells and on the surface of kidney tissue. ${ }^{349}$ Critical adhesion molecules on the surface of renal tissue include the selectin and intercellular adhesion molecule families. ${ }^{350,351}$ Particularly critical on the leukocyte surface are the anti-adhesion molecules CD43 and CD45 and the $\beta 2$-integrin family of proadhesion molecules. ${ }^{352-355}$ When leukocytes are not activated, they are maintained in the circulation by CD43 and CD45, which cover one-third of their surface and extend $45 \mathrm{~nm}$ and $55 \mathrm{~nm}$, respectively, into the extracellular space. ${ }^{356,357}$ The extracellular domains of both CD43 and CD45 are heavily decorated with O-linked and N-linked carbohydrate moieties that often terminate in sialic acid. ${ }^{358}$ The strong negative charge conferred by this sialic acid, coupled with abundance and length, allow CD43 and CD45 to prevent leukocyte adhesion. When leukocytes are activated, there is a downregulation of CD43 and CD45 along with a reduction in their sialylation and a concomitant up-regulation of the proadhesive $\beta 2$-integrin family. ${ }^{358-363}$ The induction of this reciprocal expression of anti-adhesion and pro-adhesion forces results in leukocytes acquiring an adhesive phenotype capable of extravasation and infiltration into organs such as the kidney (figure 2).

The $\beta 2$-integrin family comprises four heterodimers, composed of a common beta subunit encoded by the CD18 gene linked with one of four distinct alpha subunits encoded by the CD11a, CD11b, CD11c and CD11d genes. ${ }^{352,353}$ The $\mathrm{CD} 11 \mathrm{a} / \mathrm{CD} 18$ heterodimer is present on the surface of virtually all leukocytes, while CD11d/CD18 is expressed predominantly on myelomonocytic cells. CD11b/CD18 is expressed on natural killer and mature myeloid cells, and 
CD11c/CD18 expression mirrors that of CD11b/CD18, but also extends to dendritic cells, some cytotoxic T-lymphocyte clones, and some activated B and T-lymphocytes. Since the CD18 gene is active in all leukocytes, it is the more selective expression of the CD11 genes that dictates the specific celltypes on which the different CD11/CD18 heterodimers are present. The pattern of CD11 and CD18 production dictates that during activation macrophages exhibit induced expression of all four heterodimers that comprise the $\beta 2$-integrin family.

The increase in $\beta 2$-integrin function that occurs during leukocyte activation is caused by a number of mechanisms. The most rapid increase in function is caused by increased

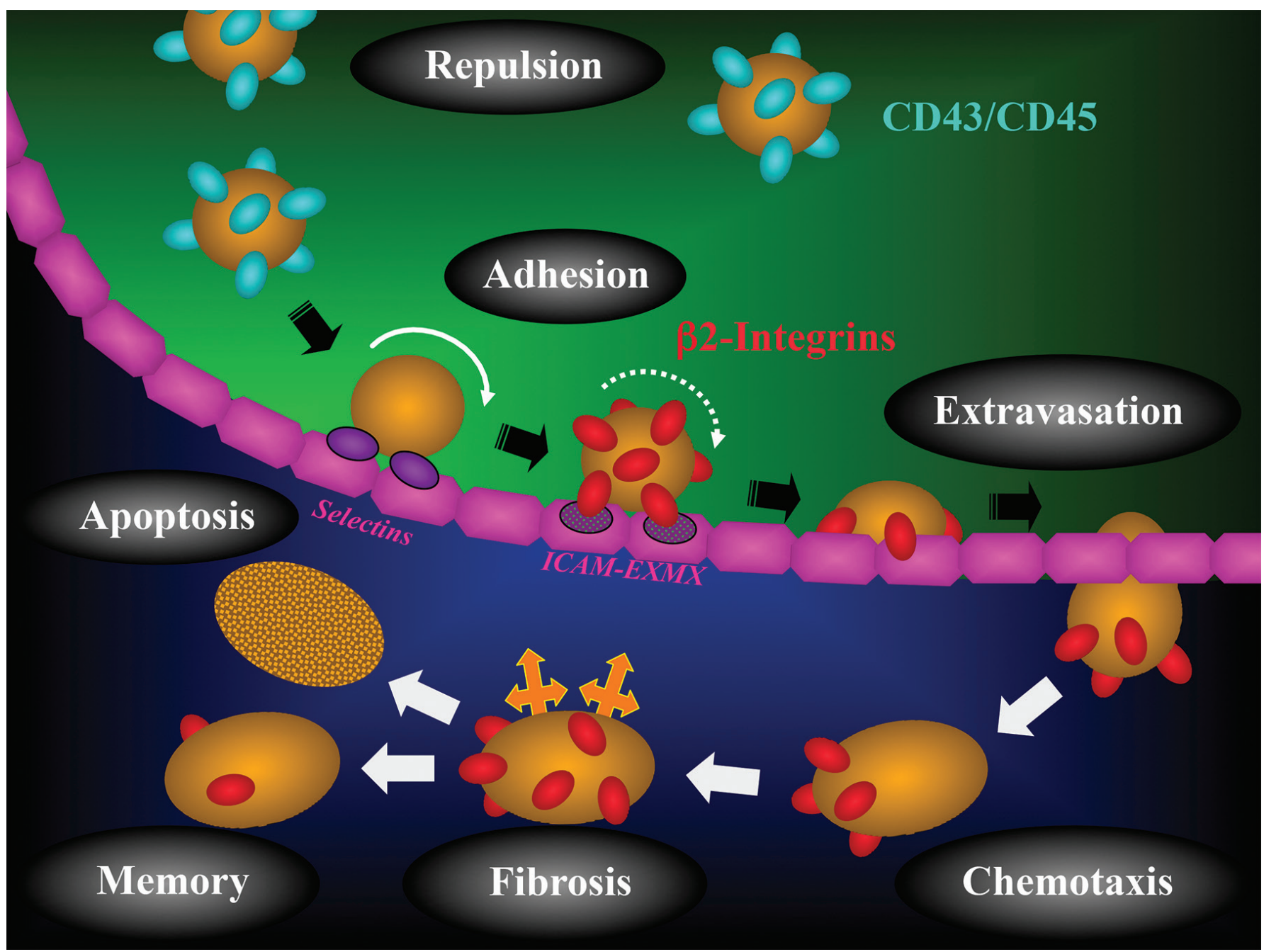

Figure 2. Recruitment of inflammatory leukocytes into renal tissue. When leukocytes (orange spheres) are nonactivated they are maintained in the circulation by repulsive forces conferred by CD43 and CD45 (blue ellipsoids) expressed on their surface. Leukocytes are activated by hypoxia either directly or indirectly as a result of responding to chemokines and cytokines released from hypoxic kidney tissue. The initial consequence of this activation is that the expression of anti-adhesive CD43 and CD45 is reduced allowing leukocytes to engage in fast-rolling along arterial cell walls (pink octahedrons) tethered by endothelial selectins (purple ellipsoids) binding leukocyte carbohydrate moieties. Fast-rolling is first slowed and then halted by $\beta 2$-integrins (red ellipsoids) being induced on the leukocyte surface and binding endothelial extracellular matrix and intercellular adhesion molecules (ICAM-EXMX) (speckled purple ellipsoids). The $\beta 2$-integrins subsequently mediate extravasation and chemotaxis through the traction they impart at the leukocyte leading-surface. Once embedded within renal tissue activated leukocytes drive fibrosis through phagocytosis, self-inflicted apoptosis and the release of cytokines and chemokines (orange arrowed-crosses) that induce the activation or apoptosis of surrounding cells and recruit additional inflammatory cells from the circulation. The vast majority of infiltrating inflammatory leukocytes eventually undergo apoptosis. However, a small proportion can remain resident with reduced $\beta 2$-integrin expression and "memory" that allows rapid re-activation. 
affinity and avidity of $\beta 2$-integrin molecules already at the leukocyte surface. ${ }^{364}$ The next wave of increased function results from the mobilization to the leukocyte surface of premade pools of the $\beta 2$-integrins. ${ }^{365}$ Finally, in order that leukocyte adhesion can be sustained, there is transcriptional induction of the $\beta 2$-integrin genes. ${ }^{360}$

Since transcriptional induction of $\beta 2$-integrin gene expression plays a vital role in macrophage function, work was undertaken to identify the causative molecular mechanisms. ${ }^{366-371}$ Using transfection analyses and phorbol myristate acetate, it was established for each $\beta 2$-integrin gene that the proximal promoter region is sufficient to drive a pattern of inducible expression in vitro which mimics that of the endogenous gene in vivo. ${ }^{360}$ In subsequent studies it was determined that GA-binding proteins alpha and beta mediate induction of the CD18 gene, ${ }^{369}$ activator protein 1 , specificity protein 1 and Pur $\alpha$ mediate induction of the CD11c gene, ${ }^{368,371}$ myeloid specificity 2 and Pur $\alpha$ mediate induction of the CD11a and CD11b genes, ${ }^{262,370}$ and Pur $\alpha$ mediates induction of the CD11d gene. ${ }^{262}$

Despite $\beta 2$-integrin expression being regulated at the transcriptional level, accepted dogma held that changes in $\beta 2$-integrin expression relevant to leukocyte function occur almost exclusively after protein translation. ${ }^{364,365}$ This dogma was challenged by demonstrating that during hypoxia, transcription of the $\beta 2$-integrin genes is absolutely required for leukocytes to exhibit increased adhesion to endothelium. ${ }^{261,262}$ A second dogma in the field of leukocyte function was that hypoxia induces their adhesion not as a consequence of their sensing oxygen deprivation directly but only indirectly as a consequence of sensing inflammatory cytokines released by hypoxic tissue. ${ }^{344-346}$ Again, this dogma was challenged by demonstrating that during hypoxia leukocytes exhibit an intrinsic increase in $\beta 2$-integrin gene expression. ${ }^{261,262}$

Following activation by hypoxia, recent evidence indicates that leukocytes exacerbate the inflammatory microenvironment. Specifically, it has been demonstrated that during acute inflammatory disease, infiltrating neutrophils mold the tissue microenvironment in ways that significantly promote the stabilization of HIF. ${ }^{372}$ Microarray analysis of epithelial cells following $\beta 2$-integrin-dependent neutrophil transmigration identified the induction of a prominent cohort of HIF target genes. These studies revealed that transmigrating neutrophils rapidly deplete the local environment of molecular oxygen and "transcriptionally imprint" the surrounding tissue to induce HIF target genes.

Taken together, recent studies establish a new paradigm in which leukocytes can sense hypoxia directly and respond by HIF-1 and Pur $\alpha$ inducing transcription of the $\beta 2$-integrin genes. ${ }^{261,262}$ Under normoxic conditions Pur $\alpha$ has been shown to repress transcription of the CD43 gene. ${ }^{361,362}$ Consequently, this transcription factor appears to act as a master regulator, coordinating the reciprocal expression of anti-adhesion and pro-adhesion molecules to drive leukocyte adhesion. While hypoxia utilizes Pur $\alpha$ to induce $\beta 2$-integrin expression, it remains to be determined whether hypoxia represses expression of either CD43 or CD45, and if it does, whether Pura is involved. However, it is intriguing to note that the expression of both CD43 and CD45 is repressed under contitions of oxidative stress..$^{373,374}$

\section{Future Directions}

It has been demonstrated experimentally that intrarenal hypoxia, per se, without confounding factors such as hyperglycemia and oxidative stress, can induce nephropathy. ${ }^{100,101}$ In addition, populations such as the Navajo Nation and Tibetans who live at high altitudes exhibit increased risk of developing CKD independent of glycemic control and lipidemia status. ${ }^{375,376}$ These findings, along with a host of other studies, argue strongly in favor of a causal relationship between hypoxia and CKD ${ }^{88-101}$ As a consequence, there is increasing interest in the development of therapeutic strategies that target hypoxia and its dependent processes. Proof-of-principle of these strategies ranges from experiments performed in vitro, to testing in animals, to deployment in the clinic. The most evolved methodologies are those aimed at improving overall body oxygenation and counteracting artery narrowing. Systemic oxygenation strategies include the administration of erythropoietin to increase hematocrit levels, apparatus to effect continuous positive airway pressure, and whole-body chambers to produce an environment of $100 \%$ oxygen. ${ }^{81,83,87,110-112,377,378}$ Artery narrowing is already routinely counteracted by renal angioplasty with or without stenting and the administration of vasoconstriction inhibitors that target the renin-angiotensin-aldosterone system. ${ }^{49,379-381}$ The targeting of vasoconstriction pathways controlled through vasopressin, endothelin, and voltage dependent calcium channels are in their infancy, as is the use of vasodilators such as arginine and kallikrein. ${ }^{155,250,268,298,379,382,383}$ Beyond systemic hypooxygenation and vasoconstriction, the hypoxia-dependent processes of microvascular rarefaction, oxidative stress, leukocyte recruitment, and fibrosis all contribute to the development of CKD. A host of potential therapeutic targets exists within these areas (Table 1). However, efficacy remains proven predominantly only in vitro or in animals. A notable exception is in efforts to stabilize the expression of HIF-1 $\alpha$. During periods of brief hypoxia, this factor is induced and is renoprotective. Only when hypoxia is prolonged does HIF-1 $\alpha$ become destabilized, leading to kidney damage. This phenomenon has been harnessed in the surgical setting by the development of the technique of remote ischemic preconditioning. ${ }^{384}$ Here repeated brief episodes of hypoxia are induced by artery clamping, stent balloon inflation, or applying a tourniquet or over-inflated blood-pressure cuff to an arm or lower limb. This procedure stabilizes HIF-1 $\alpha$ in the kidney, thereby conferring protection against a subsequent period of prolonged hypoxia. ${ }^{385}$ Pre-conditioning by having cobalt chloride in drinking water or by breathing xenon, carbon monoxide, or isoflurane gas also stabilizes HIF-1 $\alpha$ and confers 
renoprotection. ${ }^{386-390}$ The clear limitation of ischemic preconditioning is that it can only be deployed against a defined episode of acute hypoxia known to be imminent, such as occurs after artery clamping in transplant surgery, or the injection of radiocontrast medium. Consequently, effort has been applied to develop pharmacological stabilizers of HIF$1 \alpha$ that can be used to treat conditions characterized by prolonged chronic hypoxia. Dominant amongst these efforts has been the development of agents that work by inhibiting HIF-1 $\alpha$ prolyl hydrolases (PHD). ${ }^{391}$ This family of three enzymes naturally down-regulate HIF- $1 \alpha$ in a manner that is dependent upon 2-oxoglutarate. Pharmacological inactivation of the PHD enzymes by 2-oxoglutarate analogues is sufficient to stabilize HIF-1 $\alpha$, but it is nonspecific for individual PHD isoforms. ${ }^{392}$ Studies performed in vitro suggest these isoforms exhibit some significant differences in substrate specificity. PHD3, for example, does not hydroxylate proline 402 within the oxygen-dependent degradation domain of HIF-1 $\alpha$, while PHD1 and 2 do so efficiently. ${ }^{393,394}$ Such observations have generated significant interest in identifying PHD-modifying therapeutics, and a number of PHD inhibitors have been described. These include antagonists of alpha-keto-glutarate, analogs of naturally occurring cyclic hydroxamates, and direct inhibitors of the prolyl hydroxylases. ${ }^{392,395}$ The most mature work in this area is the development of the PHD inhibitor FG-4592.396 This agent stabilizes HIF-1 $\alpha$ and is currently in phase 2 and 3 clinical trials for the treatment of anemia in patients with ESRD. The challenge for the future is to develop the full range of hypoxia targets that have demonstrated therapeutic potential in the laboratory (Table 1). Some that are already in clinical use are being applied in combination, such as dual inhibition of angiotensin receptors and angiotensin-converting enzyme. ${ }^{397}$ In addition, triple blockade of the aldosterone receptor, angiotensin-converting enzyme, and angiotensin receptors is also being evaluated. ${ }^{398}$ Other combinations, such as the simultaneous inhibition of angiotensin receptors and C-C chemokine receptor type 2, have proven more effective than monotherapy in animal models. ${ }^{399}$ Consequently, a future appears at hand when deployment of a personalized battery of therapeutics will deprive CKD of the hypoxia-driven forces that ferment its progression.

\section{References}

1. Fresenius Medical Care AG \& Co. ESRD patients in 2012. A global perspective. Available at: http://www.vision-fmc.com/ files/pdf_2/ESRD_Patients_2012.pdf. Accessed February 26, 2015.

2. Moeller S, Gioberge S, Brown G. ESRD patients in 2001: global overview of patients, treatment modalities and development trends. Nephrol Dial Transplant 2002;17:2071-2076.

3. Alebiosu CO, Ayodele OE. The global burden of chronic kidney disease and the way forward. Ethn Dis 2005;15:418-423.

4. National Institutes of Health, National Institute of Diabetes \& Digestive \& Kidney Diseases, Division of Kidny, Urologic, \& Hematologic Diseases. 2013 USRDS Annual Data Report. Volume 2. Atlas of end-stage renal disease in the United States. Available at: http://www.usrds.org/2013/pdf/v2_00 intro_13.pdf. Accessed February 262015
5. Coresh J, Astor BC, Greene T, Eknoyan G, Levey AS. Prevalence of chronic kidney disease and decreased kidney function in the adult US population: Third National Health and Nutrition Examination Survey. Am J Kidney Dis 2003;41:1-12.

6. Astor BC, Muntner P, Levin A, Eustace JA, Coresh J. Association of kidney function with anemia: the Third National Health and Nutrition Examination Survey (1988-1994). Arch Intern Med 2002;162:1401-1408.

7. Iseki K, Ikemiya Y, Iseki C, Takishita S. Haematocrit and the risk of developing end-stage renal disease. Nephrol Dial Transplant 2003;18:899-905.

8. Deicher R, Hori WH. Anaemia as a risk factor for the progression of chronic kidney disease. Curr Opin Nephrol Hypertens 2003;12:139-143.

9. Binley K, Askham Z, Iqball S, Spearman H, Martin L, de Alwis M, Thrasher AJ, Ali RR, Maxwell PH, Kingsman S, Naylor S. Long-term reversal of chronic anemia using a hypoxiaregulated erythropoietin gene therapy. Blood 2002;100:24062413.

10. Susztak K, Raff AC, Schiffer M, Böttinger EP. Glucose-induced reactive oxygen species cause apoptosis of podocytes and podocyte depletion at the onset of diabetic nephropathy. Diabetes 2006;55:225-233.

11. Palm F. Intrarenal oxygen in diabetes and a possible link to diabetic nephropathy. Clin Exp Pharmacol Physiol 2006;33:997-1001.

12. Palm F, Buerk DG, Carlsson PO, Hansell P, Liss P. Reduced nitric oxide concentration in the renal cortex of streptozotocininduced diabetic rats: Effects on renal oxygenation and microcirculation. Diabetes 2005;54:3282-3287.

13. Heidland A, Gerabek W, Sebekova K. Franz Volhard and Theodor Fahr: achievements and controversies in their research in renal disease and hypertension. J Hum Hypertens 2001;15:5-16.

14. Welch WJ. Intrarenal oxygen and hypertension. Clin Exp Pharmacol Physiol 2006;33:1002-1005.

15. Welch WJ, Blau J, Xie H, Chabrashvili T, Wilcox CS. Angiotensin-induced defects in renal oxygenation: role of oxidative stress. Am J Physiol Heart Circ Physiol 2005;288:H22-H28.

16. Welch WJ, Baumgärti H, Lübbers D, Wilcox CS. Renal oxygenation defects in the spontaneously hypertensive rat: role of AT1 receptors. Kidney Int 2003;63:202-208.

17. Tanaka T, Miyata T, Inagi R, Fujita T, Nangaku M. Hypoxia in renal disease with proteinuria and/or glomerular hypertension. Am J Pathol 2004;165:1979-1992.

18. Buchwald H, O'Dea TJ, Menchaca HJ, Michalek VN, Rohde TD. Effect of plasma cholesterol on red blood cell oxygen transport. Clin Exp Pharmacol Physiol 2000;27:951-955.

19. Menchaca HJ, Michalek VN, Rohde TD, O’Dea TJ, Buchwald H. Decreased blood oxygen diffusion in hypercholesterolemia. Surgery 1998;124:692-698.

20. Buchwald H, Menchaca HJ, Michalek VN, Rohde TD, Hunninghake DB, O'Dea TJ. Plasma cholesterol: an influencing factor in red blood cell oxygen release and cellular oxygen availability. J Am Coll Surg 2000;191:490-497.

21. Heyman SN, Goldfarb M, Rosenberger C, Shina A, Rosen S. Effect of nicotine on the renal microcirculation in anesthetized rats: a potential for medullary hypoxic injury? Am J Nephrol 2005;25:226-232.

22. Orth SR, Ritz E. The renal risks of smoking: an update. Curr Opin Nephrol Hypertens 2002;11:483-488.

23. Wesson DE. The relationship of cigarette smoking to end-stage renal disease. Semin Nephrol 2003;23:317-322. 
24. Ejerblad E, Fored CM, Lindblad P, Fryzek J, Dickman PW, Elinder CG, McLaughlin JK, Nyrén O. Association between smoking and chronic renal failure in a nationwide populationbased case-control study. J Am Soc Nephrol 2004;15:21782185.

25. Ritz E, Benck U, Franek E, Keller C, Seyfarth M, Clorius J. Effects of smoking on renal hemodynamics in healthy volunteers and in patients with glomerular disease. J Am Soc Nephrol 1988;9:1798-1804.

26. Hess W. [Affinity of oxygen for hemoglobin - its significance under physiological and pathological conditions.] [Article in German] Anaesthesist 1987;36:455-467.

27. Urbanetti JS. Carbon monoxide poisoning. Prog Clin Biol Res 1981;51:355-385.

28. Schwela D. Air pollution and health in urban areas. Rev Environ Health 2000;15:13-42.

29. Badman DG, Jaffe ER. Blood and air pollution: state of knowledge and research needs. Otolaryngol Head Neck Surg 1996;114:205-208.

30. Brook RD, Brook JR, Urch B, Vincent R, Rajagopalan S, Silverman F. Inhalation of fine particulate air pollution and ozone causes acute arterial vasoconstriction in healthy adults. Circulation 2002;105:1534-1536.

31. Rundell KW, Hoffman JR, Caviston R, Bulbulian R, Hollenbach AM. Inhalation of ultrafine and fine particulate matter disrupts systemic vascular function. Inhal Toxicol 2007;19:133-140.

32. Salvi S, Blomberg A, Rundell B, Kelly F, Sandstrom T, Holgate ST, Frew A. (1999). Acute inflammatory responses in the airways and peripheral blood after short-term exposure to diesel exhaust in healthy human volunteers. Am J Respir Crit Care Med 1999;159:702-709.

33. van Eeden SF, Tan WC, Suwa T, Mukae H, Terashima T, Fujii T, Qui D, Vincent R, Hogg JC. Cytokines involved in the systemic inflammatory response induced by exposure to particulate matter in air pollutants $\left(\mathrm{PM}_{10}\right)$. Am J Respir Crit Care Med 2001;164:826-830.

34. Wang XR, Christiani DC. Respiratory symptoms and functional status in workers exposed to silica, asbestos, and coal mine dusts. J Occup Environ Med 2000;42:1076-1084.

35. Goldsmith JR, Goldsmith DF. Fiberglass or silica exposure and increased nephritis or ESRD (end-stage renal disease). Am J Ind Med 1993;23:873-881.

36. Meo SA, Al-Drees AM. Lung function among non-smoking wheat flour mill workers. Int J Occup Med Environ Health 2005; 18:259-264.

37. Wang XR, Zhang HX, Sun BX, Dai HL, Hang JQ, Eisen EA, Wegman DH, Olenchock SA, Christiani DC. A 20-year follow-up study on chronic respiratory effects of exposure to cotton dust. Eur Respir J 2005;26:881-886.

38. Krysinska-Traczyk E, Skorska C, Prazmo Z, Sitkowska J, Cholewa G, Dutkiewicz J. Exposure to airborne microorganisms, dust and endotoxin during flax scutching on farms. Ann Agric Environ Med 2004;11:309-317.

39. Dutkiewicz J, Olenchock S, Krysinska-Traczyk E, Skorska C, Sitkowska J, Prazmo Z. Exposure to airborne microorganisms in fiberboard and chipboard factories. Ann Agric Environ Med 2001;8:191-199.

40. Shen YE, Sorenson WG, Lewis DM, Olenchock SA. Microbiological analysis and inflammatory effects of settled dusts from rice and hay. Biomed Environ Sci 1990;3:353-363.

41. Halatek T, Sinczuk-Walczak H, Janasik B, Trzcinka-Ochocka M, Winnicka R, Wasowicz W. Health effects and arsenic species in urine of copper smelter workers. J Environ Sci Health A Tox Hazard Subst Environ Eng 2014;49:787-797.
42. Lue SH, Wellenius GA, Wilker EH, Mostofsky E, Mittleman MA. Residential proximity to major roadways and renal function. J Epidemiol Community Health 2013;67:629-634.

43. Novick AC, Pohl MA, Schrieber M, Gifford RW Jr, Vidt DG. Revascularization for preservation of renal function in patients with atherosclerotic renovascular disease. J Urol 1983;129:907-912.

44. Gainer JL. Hypoxia and atherosclerosis: re-evaluation of an old hypothesis. Atherosclerosis 1987;68:263-266.

45. Shanley PF. The pathology of chronic renal ischemia. Semin Nephrol 1996;16:21-32.

46. Jono S, Shioi A, Ikari Y, Nishizawa Y. Vascular calcification in chronic kidney disease. J Bone Miner Metab 2006;24:176-181.

47. McCullough PA. Cardiorenal risk: an important clinical intersection. Rev Cardiovasc Med 2002;3:71-76.

48. Massy ZA, Keane WF. Pathogenesis of atherosclerosis. Semin Nephrol 1996;16:12-20.

49. Anderson JL, Halperin JL, Albert NM, Bozkurt B, Brindis RG, Curtis LH, DeMets D, Guyton RA, Hochman JS, Kovacs RJ, Ohman EM, Pressler SJ, Sellke FW, Shen WK. Management of patients with peripheral artery disease (compilation of 2005 and 2011 ACCF/AHA guideline recommendations): a report of the American College of Cardiology Foundation/ American Heart Association task force on practice guidelines. Circulation 2013;127:1425-1443.

50. Nesbitt E, Schmidt-Trucksass A, Il'yasov KA, Weber H, Huonker M, Laubenberger J, Keul J, Hennig J, Langer M. Assessment of arterial blood flow characteristics in normal and atherosclerotic vessels with fast Fourier flow method. MAGMA 2000;10:27-34.

51. Wasserman SM, Mehraban F, Komuves LG, Yang RB, Tomlinson JE, Zhang Y, Spriggs F, Topper JN. Gene expression profile of human endothelial cells exposed to sustained fluid shear stress. Physiol Genomics 2002; 12:13-23.

52. Kleinstreuer C, Hyun S, Buchanan JR Jr, Longest PW, Archie JP Jr, Truskey GA. Hemodynamic parameters and early intimal thickening in branching blood vessels. Crit Rev Biomed Eng 2001;29:1-64.

53. Lameire N, Van Biesen W, Vanholder R. Acute renal failure. Lancet 2005;365:417-430.

54. Klenzak J, Himmelfarb J. Sepsis and the kidney. Crit Care Clin 2005;21:211-222.

55. Kon V, Badr KF. Biological actions and pathophysiologic significance of endothelin in the kidney. Kidney Int 1991;40:1-12.

56. Heyman SN, Reichman J, Brezis M. Pathophysiology of radiocontrast nephropathy: a role for medullary hypoxia. Invest Radiol 1999;34:685-691.

57. Heyman SN, Rosenberger C, Rosen S. Regional alterations in renal haemodynamics and oxygenation: a role in contrast medium-induced nephropathy. Nephrol Dial Transplant 2005;20:i6-i11.

58. Prasad PV, Priatna A, Spokes K, Epstein FH. Changes in intrarenal oxygenation as evaluated by BOLD MRI in a rat kidney model for radiocontrast nephropathy. J Magn Reson Imaging 2001;13:744-747.

59. Weisbord SD, Palevsky PM. Radiocontrast-induced acute renal failure. J Intensive Care Med 2005;20:63-75.

60. Heyman SN, Brezis M, Epstein FH, Spokes K, Silva P, Rosen $\mathrm{S}$. Early renal medullary hypoxic injury from radiocontrast and indomethacin. Kidney Int 1991;40:632-642.

61. Liss P, Nygren A, Erikson U, Ulfendahl HR. Injection of low and iso-osmolar contrast medium decreases oxygen tension in the renal medulla. Kidney Int 1998;53:698-702. 
62. Carmichael P, Carmichael AR. Acute renal failure in the surgical setting. ANZ J Surg 2003;73:144-153.

63. Mangano CM, Diamondstone LS, Ramsay JG, Aggarwal A, Herskowitz A, Mangano DT. Renal dysfunction after myocardial revascularization: risk factors, adverse outcomes, and hospital resource utilization. The Multicenter Study of Perioperative Ischemia Research Group. Ann Intern Med 1998; 128:194-203.

64. Helling TS. Ruminations of an ordinary hepatic surgeon: a journey through the pitfalls of major liver resections. J Gastrointest Surg 2002;6:625-629.

65. Zvara DA. Thoracoabdominal aneurysm surgery and the risk of paraplegia: contemporary practice and future directions. J Extra Corpor Technol 2002;34:11-17.

66. Dragun D, Hoff U, Park JK, Qun Y, Schneider W, Luft FC, Haller H. Ischemia-reperfusion injury in renal transplantation is independent of the immunologic background. Kidney Int 2000;58:2166-2177.

67. Wang WZ, Anderson GL. Intervention approaches against I/Rinduced arterial insufficiency in reconstructive surgery. Hand Clin 2001; 17:357-369.

68. Padanilam BJ, Lewington AJ. Molecular mechanisms of cell death and regeneration in acute ischemic renal injury. Curr Opin Nephrol Hypertens 1999;8:15-19.

69. Takahama T. [Post-operative complications after hepatopancreatoduodenectomy (HPD).] [Article in Japanese] Nippon Geka Gakkai Zasshi 2001;102:220-225.

70. Hessel EA $2^{\text {nd }}$. Abdominal organ injury after cardiac surgery. Semin Cardiothorac Vasc Anesth 2004;8:243-263.

71. Eckert DJ, Jordan AS, Merchia P, Malhotra A. Central sleep apnea: Pathopysiology and treatment. Chest 2007; 131:595-607.

72. White DP. Sleep apnea. Proc Am Thorac Soc 2006;3:124-128.

73. Wiegand L, Zwillich CW. Obstructive sleep apnea. Dis Mon 1994;40:197-252.

74. Kraus MA, Hamburger RJ. Sleep apnea in renal failure. Adv Perit Dial 1997;13:88-92.

75. Perl J, Unruh ML, Chan CT. Sleep disorders in end-stage renal disease: 'Markers of inadequate dialysis'? Kidney Int 2006;70:1687-1693.

76. Zoccali C, Mallamaci F, Tripepi G. Traditional and emerging cardiovascular risk factors in end-stage renal disease. Kidney Int 2003;85(Suppl):S105-S110.

77. Prabhakar NR. Oxygen sensing during intermittent hypoxia: cellular and molecular mechanisms. J Appl Physiol 2001;90:1986-1994.

78. Lahiri S, Di Giulio C, Roy A. Lessons from chronic intermittent and sustained hypoxia at high altitudes. Respir Physiol Neurobiol 2002;130:223-233.

79. Lavie L. Obstructive sleep apnoea syndrome - an oxidative stress disorder. Sleep Med Rev 2003;7:35-51.

80. Chiang AA. Obstructive sleep apnea and chronic intermittent hypoxia; a review. Chin J Physiol 2006;49:234-243.

81. Sardo L, Palange P, Di Mario F, Barbano B, Gigante A, Mordenti M, Steffanina A, Bonini M, Amoroso A, Vaccaro F, Cianci R. Intrarenal hemodynamic and oxidative stress in patients with obstructive sleep apnea syndrome. Sleep Breath 2015; 19:1205-1212.

82. Weiss JW, Liu MDY, Huang J. Physiological basis for a causal relationship of obstructive sleep apnoea to hypertension. Exp Physiol 2007;92:21-26.

83. Pressman MR, Benz RL, Schleifer CR, Peterson DD. Sleep disordered breathing in ESRD: acute beneficial effects of treatment with nasal continuous positive airway pressure. Kidney Int 1993;43:1134-1139.

84. Zoccali C, Mallamaci F, Tripepi G. Nocturnal hypoxemia: a neglected cardiovascular risk factor in end-stage renal disease? Blood Purif 2002;20:120-123.
85. Launois-Rollinat S. [Harmful effects of chronic intermittent hypoxia.] [Article in French] Rev Mal Respir 2006;23:7S116-7S119.

86. Foster GE, Poulin MJ, Hanly PJ. Intermittent hypoxia and vascular function: implications for obstructive sleep apnoea. Exp Physiol 2007;92:51-65.

87. Kinebuchi S, Kazama JJ, Satoh M, Sakai K, Nakayama H, Yoshizawa H, Narita I, Suzuki E, Gejyo, F. Short-term use of continuous positive airway pressure ameliorates glomerular hyperfiltration in patients with obstructive sleep apnoea syndrome. Clin Sci 2004;107:317-322.

88. Fine LG, Bandyopadhay D, Norman JT. Is there a common mechanism for the progression of different types of renal diseases other than proteinuria? Towards the unifying theme of chronic hypoxia. Kidney Int Suppl 2000;75:S22-S26.

89. Eckardt KU, Bernhardt WM, Weidemann A, Warnecke C, Rosenberger C, Wiesener MS, William C. Role of hypoxia in the pathogenesis of renal disease. Kidney Int 2005;99(Suppl):S46-S51.

90. Nangaku M. Chronic hypoxia and tubulointestinal injury: a final common pathway to end-stage renal failure. J Am Soc Nephrol 2006; 17:17-25.

91. Matsumoto M, Tanaka T, Yamamoto T, Noiri E, Miyata T, Inagi R, Fujita T, Nangaku M. Hypoperfusion of peritubular capillaries induces chronic hypoxia before progression of tubulointerstitial injury in a progressive model of rat glomerulonephritis. J Am Soc Nephrol 2004;15:1574-1581.

92. Norman JT, Fine LG. Intrarenal oxygenation in chronic renal failure. Clin Exp Pharmacol Physiol 2006;33:989-996.

93. Brezis M, Rosen S. Hypoxia of the renal medulla--its implications for disease. N Engl J Med 1995;332:647-655.

94. Rosenberger C, Rosen S, Shina A, Bernhardt W, Wiesener MS, Frei U, Eckardt KU, Heyman SN. Hypoxia-inducible factors and tubular cell survival in isolated perfused kidneys. Kidney Int 2006;70:60-70.

95. Haase VH. The VHL/HIF oxygen-sensing pathway and its relevance to kidney disease. Kidney Int 2006;69:1302-1307.

96. Heyman SN, Khamaisi M, Rosen S, Rosenberger C. Renal parenchymal hypoxia, hypoxia response and the progression of chronic kidney disease. Am J Nephrol 2008;28:998-1006.

97. Mimura I, Nangaku M. The suffocating kidney: tubulointerstitial hypoxia in end-stage renal disease. Nat Rev Nephrol 2010;6:667-678

98. Ow CP, Abdelkader A, Hilliard LM, Phillips JK, Evans RG. Determinants of renal tissue hypoxia in a rat model of polycystic kidney disease. Am J Physiol Regul Integr Comp Physiol 2014;307:R1207-R1215.

99. Palm F, Nordquist L. Renal tubulointerstitial hypoxia: cause and consequence of kidney dysfunction. Clin Exp Pharmacol Physiol 2011;38:474-480.

100. Friederich-Persson M, Thörn E, Hansell P, Nangaku M, Levin M, Palm F. Kidney hypoxia, attributable to increased oxygen consumption, induces nephropathy independently of hyperglycemia and oxidative stress. Hypertension 2013;62:914-919.

101. Friederich-Persson M, Persson P, Fasching A, Hansell P, Nordquist L, Palm F. Increased kidney metabolism as a pathway to kidney tissue hypoxia and damage: effects of triiodothyronine and dinitrophenol in normoglycemic rats. Adv Exp Med Biol 2013;789:9-14.

102. Brezis M, Rosen S, Silva P, Epstein FH. Renal ischemia: a new perspective. Kidney Int 1984;26:375-383.

103. Lubbers DW, Baumgärtl H. Heterogeneities and profiles of oxygen pressure in brain and kidney as examples of the $\mathrm{pO} 2$ distribution in the living tissue. Kidney Int 1997;51:372-380.

104. Schurek HJ, Jost U, Baumgärtl H, Bertram H, Heckmann U. Evidence for a preglomerular oxygen diffusion shunt in rat renal cortex. Am J Physiol 1990;259:F910-F915. 
105. Zhang W, Edwards A. Oxygen transport across vasa recta in the renal medulla. Am J Physiol Heart Circ Physiol 2002;283:H1042-H1055.

106. Zimmerhack1 B, Robertson CR, Jamison RL. The microcirculation of the renal medulla. Circ Res 1985;57:657-667.

107. Pappeneimer JR, Kinter WB. Hematocrit ratio of blood within mammalian kidney and its significance for renal hemodynamics. Am J Physiol 1956;185:377-390.

108. Ullrich KJ, Pehling G, Stoeckle H. [Hemoglobin concentration, erythrocyte count and hematocrit in the blood of the collecting tubules.] [Article in German] Pflugers Arch Gesamte Physiol Menschen Tiere. 1961;273:573-578.

109. Maxwell PH, Osmond MK, Pugh CW, Heryet A, Nicholls LG, Tan CC, Doe BG, Ferguson DJ, Johnson MH, Ratcliffe PJ. Identification of the renal erythropoietin-producing cells using transgenic mice. Kidney Int 1993;44:1149-1162.

110. Ates E, Yalcin AU, Yilmaz S, Koken T, Tokyol C. Protective effect of erythropoietin on renal ischemia and reperfusion injury. ANZ J Surg 2005;75:1100-1105.

111. Johnson DW, Forman C, Vesey DA. Novel renoprotective actions of erythropoietin: new uses for an old hormone. Nephrology 2006;11:306-312.

112. Song YR, Lee T, You SJ, Chin HJ, Chae DW, Lim C, Park KH, Han S, Kim JH, Na KY. Prevention of acute kidney injury by erythropoietin in patients undergoing coronary artery bypass grafting: a pilot study. Am J Nephrol 2009;30:253-260.

113. Patel NSA, Kerr-Peterson HL, Brines M, Collino M, Rogazzo M, Fantozzi R, Wood EG, Johnson FL, Yaqoob MM, Cerami A, Thiemermann C. Delayed administration of pyroglutamate helix B surface peptide (pHBSP), a novel nonerythropoietic analog of erythropoietin, attenuates acute kidney injury. Mol Med 2012;18:719-727.

114. Chattong S, Tanamai J, Kiatsomchai P, Nakatsu M, Sereemaspun A, Pimpha N, Praditpornsilpa K, Rojanathanes R, Sethpakadee A, Tungsanga K, Eiam-Ong S, Manotham K. Glutaraldehyde erythropoietin protects kidney in ischaemia/ reperfusion injury without increasing red blood cell production. Br. J. Pharmacol 2013;168:189-199.

115. Brines M, Grasso G, Fiordaliso F, Sfacteria A, Ghezzi P, Fratelli M, Latini R, Xie QW, Smart J, Su-Rick CJ, Pobre E, Diaz D, Gomez D, Hand C, Coleman T, Cerami A. Erythropoietin mediates tissue protection through an erythropoietin and common beta-subunit heteroreceptor. Proc Natl Acad Sci USA 2004;101:14907-14912.

116. Breggia AC, Wojchowski DM, Himmelfarb J. JAK2/Y343/ STAT5 signaling axis is required for erythropoietin-mediated protection against ischemic injury in primary renal tubular epithelial cells. Am J Physiol Renal Physiol 2008;295:F1689-F1695.

117. Rusai K, Prókai A, Szebeni B, Fekete A, Treszl A, Vannay A, Müller V, Reusz G, Heemann U, Lutz J, Tulassay T, Szabó AJ. Role of serum and glucocorticoid-regulated kinase-1 in the protective effects of erythropoietin during renal ischemia/ reperfusion injury. Biochem Pharmacol 2010;79:1173-1181.

118. Sharples EJ, Patel N, Brown P, Stewart K, Mota-Philipe H, Sheaff M, Kieswich J, Allen D, Harwood S, Raftery M, Thiemermann C, Yaqoob MM. Erythropoietin protects the kidney against the injury and dysfunction caused by ischemia-reperfusion. J Am Soc Nephrol 2004;15:2115-2124.

119. Spandou E, Tsouchnikas I, Karkavelas G, Dounousi E, Simeonidou C, Guiba-Tziampiri O, Tsakiris D. Erythropoietin attenuates renal injury in experimental acute renal failure ischaemic/reperfusion model. Nephrol Dial Transplant 2006;21:330-336.
120. Johnson DW, Pat B, Vesey DA, Guan Z, Endre Z, Gobe GC. Delayed administration of darbepoetin or erythropoietin protects against ischemic acute renal injury and failure. Kidney Int 2006;69:1806-1813.

121. Wang G, Huang H, Wu H, Wu C, Xu Y, Wang L, Liu X, Wang C, Shen Y, Li D, Jung H. Erythropoietin attenuates cardiopulmonary bypass-induced renal inflammatory injury by inhibiting nuclear factor-kB p65 expression. Eur J Pharmacol 2012;689:154-159.

122. Hu L, Yang C, Zhao T, Xu M, Tang Q, Yang B, Rong R, Zhu T. Erythropoietin ameliorates renal ischemia and reperfusion injury via inhibiting tubulointerstitial inflammation. J Surg Res 2012;176:260-266.

123. Ardalan MR, Estakhri R, Hajipour B, Ansarin K, Asi NA, Nasirizade MR, Azar AN, Ghorbanihaghjou A, Vatankhah AM, Esmaili HA. Erythropoietin ameliorates oxidative stress and tissue injury following renal ischemia/reperfusion in rat kidney and lung. Med Princ Pract 2013;22:70-74.

124. Wittmann I, Molnar GA, Degrell P, Wagner Z, Tamasko M, Laczy B, Brasnyo P, Wagner L, Nagy J. Prevention and treatment of diabetic nephropathy. Diabetes Res Clin Pract 2005;68:S36-S42.

125. Mogyorosi A, Ziyadeh FN. Diabetic nephropathy. In: Massry SG, Glassock RJ, eds. Textbook of Nephrology. $4^{\text {th }}$ ed. Philadelphia: Lippincott, Williams and Wilkens; 2001. 845-895.

126. Ayo SH, Radnik RA, Garoni JA, Glass WF II, Kreisberg JI. High glucose causes an increase in extracellular matrix proteins in cultured mesangial cells. Am J Pathol 1990;136:1339-1348.

127. Natarajan R, Gonzales N, Xu L, Nadler J. Vascular smooth muscle cells exhibit increased growth response to elevated glucose. Biochem Biophys Res Commun 1992;87:552-560.

128. Wolf G, Sharma K, Chen Y, Erickson M, Ziyadeh FN. High glucose-induced proliferation in mesangial cells is reversed by autocrine TGF- $\beta 1$. Kidney Int 1992;42:647-656.

129. Sodhi CP, Phadke SA, Batlle D, Sahai A. Hypoxia and high glucose cause exaggerated mesangial cell growth and collagen synthesis: role of osteopontin. Am J Physiol Renal Physiol 2001;280:F667-F674.

130. Koya D, King GL. Protein kinase C activation and the development of diabetic complications. Diabetes 1998;47:859-866.

131. Tucker MA, Chang P, Prince C, Gillespie GY, Mapstone TB. TPA-mediated regulation of osteopontin in human malignant glioma cells. Anticancer Res 1998;18:807-812.

132. Takemoto M, Yokote K, Yamazaki M, Ridall AL, Butler WT, Matsumoto T, Tamura K, Saito Y, Mori S. Enhanced expression of osteopontin by high glucose in cultured rat aortic smooth muscle cells. Biochem Biophys Res Commun 1999;258:722-726.

133. Park CW, Kim JH, Lee JH, Kim YS, Ahn HJ, Shin YS, Kim SY, Choi EJ, Chang YS, Bang BK. High glucose-induced intercellular adhesion molecule-1 (ICAM-1) expression through an osmotic effect in rat mesangial cells is PKC-NFkappa B-dependent. Diabetologia 2000;43:1544-1553.

134. Sodhi CP, Batlle D, Sahai A. Osteopontin mediates hypoxiainduced proliferation of cultured mesangial cells; role of PKC and p38 MAPKe. Kidney Int 2000;58:691-700.

135. Ruoslahti E, Engvall E. Integrins and vascular extracellular matrix assembly. J Clin Invest 1997;99:1149-1152.

136. Allen TJ, Cooper ME, Lan HY. Use of genetic mouse models in the study of diabetic nephropathy. Curr Atherscler Rep 2004;6:197-202.

137. Cohen MP, Lautenslager GT, Shearman CT. Increased urinary type IV collagen marks the development of glomerular pathology in diabetic $\mathrm{d} / \mathrm{db}$ mice. Metabolism 2001;50:1435-1440. 
138. Koya D, Haneda M, Nakagawa H, Isshiki K, Sato H, Maeda S, Sugimoto T, Yasuda H, Kashiwagi A, Ways DK, King GL, Kikkawa R. Amelioration of accelerated diabetic mesangial expansion by treatment with a PKC inhibitor in diabetic $\mathrm{db} /$ $\mathrm{db}$ mice, a rodent model for type 2 diabetes. FASEB J 2000;14:439-447.

139. Ziyadeh F, Hoffman B, Han D, Iglesias-de la Cruz C, Hong S, Isono $\mathrm{M}$, Chen $\mathrm{S}$, McGowen T, Sharma K. Long-term prevention of renal insufficiency excess matrix gene expression and glomerular mesangial matrix expansion by treatment with monoclonal antitransforming growth factor- $\beta$ antibody in $\mathrm{db} / \mathrm{db}$ diabetic mice. Proc Natl Acad Sci USA 2000;97:8015-8020.

140. Makino H, Miyamoto Y, Sawai K, Mori K, Mukoyama M, Nakao K, Yoshimasa Y, Suga SI. Altered gene expression related to glomerulogenesis and podocyte structure in early diabetic nephropathy of $\mathrm{db} / \mathrm{db}$ mice and its restoration by pioglitazone. Diabetes 2006;55:2747-2756.

141. Johnson RJ, Feig DI, Nakagawa T, Sanchez-Lozada LG, Rodriguez-Iturbe B. Pathogenesis of essential hypertension: historical paradigms and modern insights. J Hypertens 2008;26:381-391.

142. Saleh MA, Pollock DM. Endothelin in renal inflammation and hypertension. Contrib Nephrol 2011;172:160-170.

143. Tian XY, Wong WT, Leung FP, Zhang Y, Wang YX, Lee HK, $\mathrm{Ng} \mathrm{CF}$, Chen ZY, Yao X, Au CL, Lau CW, Vanhoutte PM, Cooke JP, Huang Y. Oxidative stress-dependent cyclooxygenase-2-derived prostaglandin $\mathrm{f}(2 \alpha)$ impairs endothelial function in renovascular hypertensive rats. Antioxid Redox Signal 2012;16:363-372.

144. Gomez SI, Warner L, Haas JA, Bolterman RJ, Textor SC, Lerman LO, Romero JC. Increased hypoxia and reduced renal tubular response to furosemide detected by BOLD magnetic resonance imaging in swine renovascular hypertension. Am J Physiol Renal Physiol 2009;297:F981-F986.

145. Zhu Q, Wang Z, Xia M, Li PL, Van Tassell BW, Abbate A, Dhaduk R, Li N. Silencing of hypoxia-inducible factor- $1 \alpha$ gene attenuated angiotensin II-induced renal injury in Sprague-Dawley rats. Hypertension 2011;58:657-664.

146. Adler S, Huang H. Impaired regulation of renal oxygen consumption in spontaneously hypertensive rats. J Am Soc Nephrol 2002;13:1788-1794.

147. Brezis M, Greenfeld Z, Shina A, Rosen S. Angiotensin II augments medullary hypoxia and predisposes to acute renal failure. Eur J Clin Invest 1990;20:199-207.

148. Hansell P, Welch WJ, Blantz RC, Palm F. Determinants of kidney oxygen consumption and their relationship to tissue oxygen tension in diabetes and hypertension. Clin Exp Pharmacol Physiol 2013;40:123-137.

149. Welch WJ, Mendonca M, Aslam S, Wilcox CS. Roles of oxidative stress and $\mathrm{AT}_{1}$ receptors in renal hemodynamics and oxygenation in the postclipped $2 \mathrm{~K}, 1 \mathrm{C}$ kidney. Hypertension 2003;41:692-696.

150. Zatz R, Baylis C. Chronic nitric oxide inhibition model six years on. Hypertension 1998;32:958-964.

151. Simão S, Gomes P, Pinto V, Silva E, Amaral JS, Igreja B, Afonso J, Serrão MP, Pinho MJ, Soares-da-Silva P. Agerelated changes in renal expression of oxidant and antioxidant enzymes and oxidative stress markers in male SHR and WKY rats. Exp Gerontol 2011;46:468-474.

152. Zhou XJ, Vaziri ND, Zhang J, Wang HW, Wang XQ. Association of renal injury with nitric oxide deficiency in aged SHR. Prevention by hypertension control with AT1 blockade. Kidney Int 2002;62:914-921.

153. Mihailovic-Stanojevic N, Miloradovic Z, Grujic-Milanovic J, Ivanov M, Jovovic D. Effects of angiotensin II type-1 receptor blocker losartan on age-related cardiovascular risk in spontaneously hypertensive rats. Gen Physiol Biophys 2009;28:112-118.
154. Panico C, Luo Z, Damiano S, Artigiano F, Gill P, Welch WJ. Renal proximal tubular reabsorption is reduced in adult spontaneously hypertensive rats: roles of superoxide and $\mathrm{Na}+/$ $\mathrm{H}+$ exchanger 3. Hypertension 2009;54:1291-1297.

155. Campos SB, Ori M, Dórea EL, Seguro AC. Protective effect of L-arginine on hypercholesterolemia-enhanced renal ischemic injury. Atherosclerosis 1999;143:327-334.

156. Economides PA, Caselli A, Zuo CS, Sparks C, Khaodhiar L, Katsilambros N, Horton ES, Veves A. Kidney oxygenation during water diuresis and endothelial function in patients with type 2 diabetes and subjects at risk to develop diabetes. Metabolism 2004;53:222-227.

157. Wang H, Tian JL, Feng SZ, Sun N, Chen BY, Zhang Y. The organ specificity in pathological damage of chronic intermittent hypoxia: an experimental study on rat with highfat diet. Sleep Breath 2013;17:957-965.

158. Verani RR. Obesity-associated focal segmental glomerulosclerosis: pathological features of the lesion and relationship with cardiomegaly and hyperlipidemia. Am J Kidney Dis 1992;20:629-634.

159. Caballero AE, Arora S, Saouaf R, Lim SC, Smakowski P, Park JY, King GL, LoGerfo FW, Horton ES, Veves A. Microvascular and macrovascular reactivity is reduced in subjects at risk for type 2 diabetes. Diabetes 1999;48:1856-1862.

160. Michelakis ED, Hampl V, Nsair A, Wu X, Harry G, Haromy A, Gurtu R, Archer SL. Diversity in mitochondrial function explains differences in vascular oxygen sensing. Circ Res 2002;90:1307-1315.

161. Favreau F, Rossard L, Zhang K, Desurmont T, Manguy E, Belliard A, Fabre S, Liu J, Han Z, Thuillier R, Papadopoulos $\mathrm{V}$, Hauet T. Expression and modulation of translocator protein and its partners by hypoxia reoxygenation or ischemia and reperfusion in porcine renal models. Am J Physiol Renal Physiol 2009;297:F177-F190.

162. Zager RA, Johnson A, Anderson K, Wright S. Cholesterol ester accumulation: an immediate consequence of acute in vivo ischemic renal injury. Kidney Int 2001;59:1750-1761.

163. Zager RA, Andoh T, Bennett WM. Renal cholesterol accumulation: a durable response after acute and subacute renal insults. Am J Pathol 2001;159:743-752.

164. Brown MS, Ho YK, Goldstein JL. The cholesteryl ester cycle in macrophage foam cells. Continual hydrolysis and re-esterification of cytoplasmic cholesteryl esters. J Biol Chem 1980;255:9344-9352.

165. Dimitrova-Shumkovska J, Veenman L, Ristoski T, Leschiner S, Gavish M. Chronic high fat, high cholesterol supplementation decreases $18 \mathrm{kDa}$ translocator protein binding capacity in association with increased oxidative stress in rat liver and aorta. Food Chem Toxicol 2010;48:910-921.

166. Lecanu L, Yao ZX, McCourty A, Sidahmed el-K, Orellana ME, Burnier MN, Papadopoulos V. Control of hypercholesterolemia and atherosclerosis using the cholesterol recognition/ interaction amino acid sequence of the translocator protein TSPO. Steroids 2013;78:137-146.

167. Lassance L, Haghiac M, Minium J, Catalano P, Hauguel-de Mouzon S. Obesity-induced down-regulation of the mitochondrial trnslocator protein (TSPO) impairs placental steroid production. J Clin Endocrinol Metab 2015; 100:E11-E18.

168. Pinto-Sietsma SJ, Mulder J, Janssen WM, Hillege HL, de Zeeuw D, de Jong PE. Smoking is related to albuminuria and abnormal renal function in nondiabetic persons. Ann Intern Med 2000;133:585-591.

169. Halimi JM, Giraudeau B, Vol S, Cacès E, Nivet H, Lebranchu Y, Tichet J. Effects of current smoking and smoking discontinuation on renal function and proteinuria in the general population. Kidney Int 2000;58:1285-1292. 
170. Yacoub R, Habib H, Lahdo A, Al Ali R, Varjabedian L, Atalla G, Kassis Akl N, Aldakheel S, Alahdab S, Albitar S. Association between smoking and chronic kidney disease: a case control study. BMC Public Health 2010;10:731.

171. Garcia-Esquinas E, Loeffler LF, Weaver VM, Fadrowski JJ, Navas-Acien A. Kidney function and tobacco smoke exposure in US adolescents. Pediatrics 2013;131:e1415-e1423.

172. Gambaro G, Verlato F, Budakovic A, Casara D, Saladini G, Del Prete D, Bertaglia G, Masiero M, Checchetto S, Baggio B. Renal impairment in chronic cigarette smokers. J Am Soc Nephrol 1998;9:562-567.

173. Briganti EM, Branley P, Chadban SJ, Shaw JE, McNeil JJ, Welborn TA, Atkins RC. Smoking is associated with renal impairment and proteinuria in the normal population: the AusDiab kidney study. Australian Diabetes, Obesity and Lifestyle Study. Am J Kidney Dis 2002;40:704-712.

174. Dülger H, Dönder A, Sekeroğlu MR, Erkoç R, Ozbay B. Investigation of the relationship between serum levels of cotinine and the renal function in active and passive smokers. Ren Fail 2011;33:475-479.

175. Noborisaka Y. Smoking and chronic kidney disease in healthy populations. Nephrourol Mon 2013;5:655-667.

176. Noborisaka Y, Ishizaki M, Yamada Y, Honda R, Yokoyama H, Miyao M, Tabata M. The effects of continuing and discontinuing smoking on the development of chronic kidney disease $(\mathrm{CKD})$ in the healthy middle-aged working population in Japan. Environ Health Prev Med 2013; 18:24-32.

177. Gambaro G, Bax G, Fusaro M, Normanno M, Manani SM, Zanella M, Dangelo A, Fedele D, Favaro S. Cigarette smoking is a risk factor for nephropathy and its progression in type 2 diabetes mellitus. Diabetes Nutr Metab 2001;14:337342.

178. Hellemons ME, Agarwal PK, van der Bij W, Verschuuren EA, Postmus D, Erasmus ME, Navis GJ, Bakker SJ. Former smoking is a risk factor for chronic kidney disease after lung transplantation. Am J Transplant 2011;11:2490-2498.

179. Regalado M, Yang S, Wesson DE. Cigarette smoking is associated with augmented progression of renal insufficiency in severe essential hypertension. Am J Kidney Dis 2000;35:687-694

180. Míguez-Burbano MJ, Wyatt C, Lewis JE, Rodríguez A, Duncan R. Ignoring the obvious missing piece of chronic kidney disease in HIV: cigarette smoking. J Assoc Nurses AIDS Care 2010;21:16-24.

181. Tozawa M, Iseki K, Iseki C, Oshiro S, Ikemiya Y, Takishita S. Influence of smoking and obesity on the development of proteinuria. Kidney Int 2002;62:956-962.

182. Andronico G, Romé M, Lo Cicero A, Parsi R, Seddio G, Ferraro-Mortellaro R, Buscemi S, Cerasola G. Renal plasma flow, filtration fraction and microalbuminuria in hypertensive patients: effects of chronic smoking. Nephrology (Carlton) 2005;10:483-486.

183. Chuahirun T, Khanna A, Kimball K, Wesson DE. Cigarette smoking and increased urine albumin excretion are interrelated predictors of nephropathy progression in type 2 diabetes. Am J Kidney Dis 2003;41:13-21.

184. Chase HP, Garg SK, Marshall G, Berg CL, Harris S, Jackson WE, Hamman RE. Cigarette smoking increases the risk of albuminuria among subjects with type I diabetes. JAMA 1991;265:614-617.

185. Ozkok A, Akpinar TS, Tufan F, Kanitez NA, Uysal M, Guzel M, Caliskan Y, Alisir S, Yazici H, Ecder T. Clinical characteristics and predictors of progression of chronic kidney disease in autosomal dominant polycystic kidney disease: a single center experience. Clin Exp Nephrol 2013;17:345-351.

186. Ward MM, Studenski S. Clinical prognostic factors in lupus nephritis. The importance of hypertension and smoking. Arch Intern Med 1992;152:2082-2088.
187. Orth SR. Smoking and the kidney. J Am Soc Nephrol 2002;13:1663-1672.

188. Kheradmand A, Shahbazian H. The role of pretransplant smoking on allograft survival in kidney recipients. Urol J 2005;2:36-39.

189. Sung RS, Althoen M, Howell TA, Ojo AO, Merion RM. Excess risk of renal allograft loss associated with cigarette smoking. Transplantation 2001;71:1752-1757.

190. Hallan SI, Orth SR. Smoking is a risk factor in the progression to kidney failure. Kidney Int 2011;80:516-523.

191. Manley HJ, Stack NM. Smoking cessation therapy considerations for patients with chronic kidney disease. Nephrol Nurs J 2008;35:357-363

192. Huang MF, Lin WL, Ma YC. A study of reactive oxygen species in mainstream of cigarette. Indoor Air 2005; $15: 135-140$

193. Satarug S, Moore MR. Adverse health effects of chronic exposure to low-level cadmium in foodstuffs and cigarette smoke. Environ Health Perspect 2004;112:1099-1103.

194. Cooper RG. Effect of tobacco smoking on renal function. Indian J Med Res 2006;124:261-268.

195. Jaimes EA, Tian RX, Raij L. Nicotine: the link between cigarette smoking and the progression of renal injury? Am J Physiol Heart Circ Physiol 2007;292:H76-H82.

196. Jain G, Jaimes EA. Nicotine signaling and progression of chronic kidney disease in smokers. Biochem Pharmacol 2013;86:1215-1223.

197. Rezonzew G, Chumley P, Feng W, Hua P, Siegal GP, Jaimes EA. Nicotine exposure and the progression of chronic kidney disease: role of the $\alpha 7$-nicotinic acetylcholine receptor. Am J Physiol Renal Physiol 2012;303:F304-F312.

198. Macklin KD, Maus AD, Pereira EF, Albuquerque EX, ContiFine BM. Human vascular endothelial cells express functional nicotinic acetylcholine receptors. J Pharmacol Exp Ther 1998;287:435-439.

199. Utsugisawa K, Nagane Y, Obara D, Tohgi H. Increased expression of $\alpha 7 \mathrm{nAChR}$ after transient hypoxia in PC12 cells. Neuroreport 2000;11:2209-2212.

200. Machaalani R, Ghazavi E, David RV, Hinton T, Makris A, Hennessy A. Nicotinic acetylcholine receptors (nAChR) are increased in the pre-eclamptic placenta. Hypertens Pregnancy 2015;34:227-240.

201. Asano H, Horinouchi T, Mai Y, Sawada O, Fujii S, Nishiya T, Minami M, Katayama T, Iwanaga T, Terada K, Miwa S. Nicotine- and tar-free cigarette smoke induces cell damage through reactive oxygen species newly generated by PKCdependent activation of NADPH oxidase. J Pharmacol Sci 2012;118:275-287.

202. Jaimes EA, Galceran JM, Raij L. Angiotensin II induces superoxide anion production by mesangial cells. Kidney Int 1998;54:775-784.

203. Sharma P, Evans AT, Parker PJ, Evans FJ. NADPH-oxidase activation by protein kinase C-isotypes. Biochem Biophys Res Commun 1991;177:1033-1040.

204. Arany I, Grifoni S, Clark JS, Csongradi E, Maric C, Juncos LA. Chronic nicotine exposure exacerbates acute renal ischemic injury. Am J Physiol Renal Physiol 2011;301:F125-F133.

205. Jaimes EA, DeMaster EG, Tian RX, Raij L. Stable compounds of cigarette smoke induce endothelial superoxide anion production via NADPH oxidase activation. Arterioscler Thromb Vasc Biol 2004;24:1031-1036.

206. Jaimes EA, Tian RX, Joshi MS, Raij L. Nicotine augments glomerular injury in a rat model of acute nephritis. Am J Nephrol 2009;29:319-326.

207. Hua P, Feng W, Ji S, Raij L, Jaimes EA. Nicotine worsens the severity of nephropathy in diabetic mice: implications for the progression of kidney disease in smokers. Am J Physiol Renal Physiol 2010;299:F732-F739. 
208. Gorin Y, Block K, Hernandez J, Bhandari B, Wagner B, Barnes JL, Abboud HE. Nox4 NAD(P)H oxidase mediates hypertrophy and fibronectin expression in the diabetic kidney. J Biol Chem 2005;280:39616-39626.

209. Obert DM, Hua P, Pilkerton ME, Feng W, Jaimes EA. Environmental tobacco smoke furthers progression of diabetic nephropathy. Am J Med Sci 2011;341:126-130.

210. Arany I, Reed DK, Grifoni SC, Chandrashekar K, Booz GW, Juncos LA. A novel U-STAT3-dependent mechanism mediates the deleterious effects of chronic nicotine exposure on renal injury. Am J Physiol Renal Physiol 2012;302:F722-F729.

211. Orth SR. Effects of smoking on systemic and intrarenal hemodynamics: influence on renal function. J Am Soc Nephrol 2004;15 Suppl 1:S58-S63.

212. Halimi JM, Giraudeau B, Vol S, Cacès E, Nivet H, Tichet J. The risk of hypertension in men: direct and indirect effects of chronic smoking. J Hypertens 2002;20:187-193.

213. Mann SJ, James GD, Wang RS, Pickering TG. Elevation of ambulatory systolic blood pressure in hypertensive smokers. A case-control study. JAMA 1991;265:2226-2228.

214. Boor P, Casper S, Celec P, Hurbánková M, Beno M, Heidland A, Amann K, Sebeková K. Renal, vascular and cardiac fibrosis in rats exposed to passive smoking and industrial dust fibre amosite. J Cell Mol Med 2009;13:4484-4491.

215. Evans RG, Goddard D, Eppel GA, O'Connor PM. Stability of tissue PO2 in the face of altered perfusion: a phenomenon specific to the renal cortex and independent of resting renal oxygen consumption. Clin Exp Pharmacol Physiol 2011;38:247-254.

216. Warner L, Gomez SI, Bolterman R, Haas JA, Bentley MD, Lerman LO, Romero JC. Regional decreases in renal oxygenation during graded acute renal arterial stenosis: a case for renal ischemia. Am J Physiol Regul Integr Comp Physiol 2009;296:R67-R71.

217. Textor SC, Glockner JF, Lerman LO, Misra S, McKusick MA, Riederer SJ, Grande JP, Gomez SI, Romero JC. The use of magnetic resonance to evaluate tissue oxygenation in renal artery stenosis. J Am Soc Nephrol 2008;19:780-788.

218. Gloviczki ML, Saad A, Textor SC. Blood oxygen leveldependent (BOLD) MRI analysis in atherosclerotic renal artery stenosis. Curr Opin Nephrol Hypertens 2013;22:519-524.

219. Evans RG, Eppel GA, Anderson WP, Denton KM. Mechanisms underlying the differential control of blood flow in the renal medulla and cortex. J Hypertens 2004;22:14391451.

220. Lerman LO, Textor SC, Grande JP. Mechanisms of tissue injury in renal artery stenosis: ischemia and beyond. Prog Cardiovasc Dis 2009;52:196-203.

221. Zhu XY, Chade AR, Rodriguez-Porcel M, Bentley MD, Ritman EL, Lerman A, Lerman LO. Cortical microvascular remodeling in the stenotic kidney: role of increased oxidative stress. Arterioscler Thromb Vasc Biol 2004;24:1854-1859.

222. Chade AR, Mushin OP, Xhu X, Rodriguez-Porcel M, Grande JP, Textor SC, Lerman A, Lerman LO. Pathways of renal fibrosis and modulation of matrix turnover in experimental hypercholesterolemia. Hypertension 2005;46:772-779.

223. Chade AR, Zhu X, Mushin OP, Nepoli C, Lerman A, Lerman LO. Simvastatin promotes angiogenesis and prevents microvascular remodeling in chronic renal ischemia. FASEB J 2006;20:1706-1708.

224. Iliescu R, Fernandez SR, Kelsen S, Maric C, Chade AR. Role of renal microcirculation in experimental renovascular disease. Nephrol Dial Transplant 2010;25:1079-1087.

225. Kang DH, Johnson RJ. Vascular endothelial growth factor: a new player in the pathogenesis of renal fibrosis. Curr Opin Nephrol Hypertens 2003;12:43-49.
226. Textor SC, Lerman L. Renovascular hypertension and ischemic nephropathy. Am J Hypertens 2010;23:1159-1169.

227. Gloviczki ML, Glockner JF, Crane JA, McKusick MA, Misra S, Grande JP, Lerman LO, Textor SC. Blood oxygen leveldependent magnetic resonance imaging identifies cortical hypoxia in severe renovascular disease. Hypertension 2011;58:1066-1072.

228. Gloviczki ML, Keddis MT, Garovic VD, Friedman H, Herrmann S, McKusick MA, Misra S, Grande JP, Lerman LO, Textor SC. TGF expression and macrophage accumulation in atherosclerotic renal artery stenosis. Clin $\mathrm{J}$ Am Soc Nephrol 2013;8:546-553.

229. Murphy TP, Cooper CJ, Dworkin LD, Henrich WL, Rundback JH, Matsumoto AH, Jamerson KA, D'Agostino RB. The Cardiovascular Outcomes with Renal Atherosclerotic Lesions (CORAL) study: rationale and methods. J Vasc Interv Radiol 2005; 16:1295-1300.

230. Bax L, Mali WP, Buskens E, Koomans HA, Beutler JJ, Braam B, Beek FJ, Rabelink TJ, Postma CT, Huysmans FT, Deinum J, Thien T, Schultze Kool LJ, Woittiez AJ, Kouwenberg JJ, van den Meiracker AH, Pattynama PM, van de Ven PJ, Vroegindeweij D, Doorenbos CJ, Aarts JC, Kroon AA, de Leeuw PW, de Haan MW, van Engelshoven JM, Rutten MJ, van Montfrans GA, Reekers JA, Plouin PF, La Batide Alanore A, Azizi M, Raynaud A, Harden PN, Cowling M; STAR Study Group. The benefit of STent placement and blood pressure and lipid-lowering for the prevention of progression of renal dysfunction caused by Atherosclerotic ostial stenosis of the Renal artery. The STAR-study: rationale and study design. J Nephrol 2003;16:807-812.

231. Mistry S, Ives N, Harding J, Fitzpatrick-Ellis K, Lipkin G, Kalra PA, Moss J, Wheatley K. Angioplasty and STent for Renal Artery Lesions (ASTRAL trial): rationale, methods and results so far. J Hum Hypertens 2007;21:511-515.

232. Askenazi DJ, Feig DI, Graham NM, Hui-Stickle S, Goldstein SL. 3-5 year longitudinal follow-up of pediatric patients after acute renal failure. Kidney Int 2006;69:184-189.

233. Coca SG, Singanamala S, Parikh CR. Chronic kidney disease after acute kidney injury: a systemic review and metaanalysis. Kidney Int 2012;81:442-448.

234. Mammen C, Al Abbas A, Skippen P, Nadel H, Levine D, Collet JP, Matsell DG. Long-term risk of CKD in children surviving episodes of acute kidney injury in the intensive care unit: a prospective cohort study. Am J Kidney Dis 2012;59:523-530.

235. Wald R, Quinn RR, Adhikari NK, Burns, KE, Friedrich JO, Garg AX, Harel Z, Hladunewich MA, Luo J, Mamdani M, Perl J, Ray JG; University of Toronto Acute Kidney Injury Research Group. Risk of chronic dialysis and death following acute kidney injury. Am J Med 2012;125:585-593.

236. Wald R, Quinn RR, Luo J, Li P, Scales DC, Mamdani MM, Ray JG; University of Toronto Acute Kidney Injury Research Group. Chronic dialysis and death among survivors of acute kidney injury requiring dialysis. JAMA 2009;302:1179-1185.

237. Bucaloiu ID, Kirchner HL, Norfolk ER, Hartle JE, Perkins RM. Increased risk of death and de novo chronic kidney disease following reversible acute kidney injury. Kidney Int 2012;81:477-485.

238. Chawla LS, Amdur RL, Amodeo S, Kimmel PL, Palant CE. The severity of acute kidney injury predicts progression to chronic kidney disease. Kidney Int 2011;79:1361-1369.

239. Thakar CV, Christianson A, Himmelfarb J, Leonard AC. Acute kidney injury episodes and chronic kidney disease risk in diabetes mellitus. Clin J Am Soc Nephrol 2011;6:2567-2572.

240. Belayev LY, Palevsky PM. The link between acute kidney injury and chronic kidney disease. Curr Opin Nephrol Hypertens 2014;23:149-154. 
241. Hsu CY. Yes, AKI truly leads to CKD. J Am Soc Nephrol 2012;23:967-969.

242. Tanaka S, Tanaka T, Nangaku M. Hypoxia as a key player in the AKI-to-CKD transition. Am J Physiol Renal Physiol 2014;307:F1187-F1195.

243. Conde E, Alegre L, Blanco-Sánchez I, Sáenz-Morales D, Aguado-Fraile E, Ponte B, Ramos E, Sáiz A, Jiménez C, Ordoñez A, López-Cabrera M, del Peso L, de Landázuri MO, Liaño F, Selgas R, Sanchez-Tomero JA, García-Bermejo ML. Hypoxia inducible factor 1-alpha (HIF-1 alpha) is induced during reperfusion after renal ischemia and is critical for proximal tubule cell survival. PLoS One 2012;7:e33258.

244. Hill P, Shukla D, Tran MG, Aragones J, Cook HT, Carmeliet $\mathrm{P}$, Maxwell PH. Inhibition of hypoxia inducible factor hydroxylases protects against renal ischemia-reperfusion injury. J Am Soc Nephrol 2008;19:39-46.

245. Rosenberger C, Goldfarb M, Shina A, Bachmann S, Frei U, Eckardt KU, Schrader T, Rosen S, Heyman SN. Evidence for sustained renal hypoxia and transient hypoxia adaptation in experimental rhabdomyolysis-induced acute kidney injury. Nephrol Dial Transplant 2008;23:1135-1143.

246. Tanaka T, Kojima I, Ohse T, Inagi R, Miyata T, Ingelfinger JR, Fujita T, Nangaku M. Hypoxia-inducible factor modulates tubular cell survival in cisplatin nephrotoxicity. Am J Physiol Renal Physiol 2005;289:F1123-F1133.

247. Abdelkader A, Ho J, Ow CP, Eppel GA, Rajapakse NW, Schlaich MP, Evans RG. Renal oxygenation in acute renal ischemia-reperfusion injury. Am J Physiol Renal Physiol 2014;306:F1026-F1038.

248. Redfors B, Bragadottir G, Sellgren J, Swärd K, Ricksten SE. Acute renal failure is NOT an "acute renal success" - a clinical study on the renal oxygen supply/demand relationship in acute kidney injury. Crit Care Med 2010;38:1695-1701.

249. Rosenberger C, Pratschke J, Rudolph B, Heyman SN, Schindler R, Babel N, Eckardt KU, Frei U, Rosen S, Reinke P. Immunohistochemical detection of hypoxia-inducible factor-1 alpha in human renal allograft biopsies. J Am Soc Nephrol 2007;18:343-351.

250. Basile DP, Donohoe DL, Roethe K, Mattson DL. Chronic renal hypoxia after acute ischemic injury: effects of L-arginine on hypoxia and secondary damage. Am J Physiol Renal Physiol 2003;284:F338-F348.

251. Basile DP, Fredrich K, Chelladurai B, Leonard EC, Parrish AR. Renal ischemia reperfusion inhibits VEGF expression and induces ADAMTS-1, a novel VEGF inhibitor. Am J Physiol Renal Physiol 2008;294:F928-F936.

252. Lin SL, Chang FC, Schrimpf C, Chen YT, Wu CF, Wu VC, Chiang WC, Kuhnert F, Kuo CJ, Chen YM, Wu KD, Tsai TJ, Duffield JS. Targeting endothelium-pericyte cross talk by inhibiting VEGF receptor signaling attenuates kidney microvascular rarefaction and fibrosis. Am J Pathol 2011;178:911-923.

253. Basile DP, Donohoe D, Roethe K, Osborn JL. Renal ischemic injury results in permanent damage to peritubular capillaries and influences long-term function. Am J Physiol Renal Physiol 2001;281:F887-F899.

254. Kramann R, Tanaka M, Humphreys BD. Fluorescence microangiography for quantitative assessment of peritubular capillary changes after AKI in mice. J Am Soc Nephrol 2014;25:1924-1931.

255. Mayer G. Capillary rarefaction, hypoxia, VEGF and angiogenesis in chronic renal disease. Nephrol Dial Transplant 2011;26:1132-1137.
256. Asada N, Takase M, Nakamura J, Oguchi A, Asada M, Suzuki N, Yamamura K, Nagoshi N, Shibata S, Rao TN, Fehling HJ, Fukatsu A, Minegishi N, Kita T, Kimura T, Okano H, Yamamoto M, Yanagita M. Dysfunction of fibroblasts of extrarenal origin underlies renal fibrosis and renal anemia in mice. J Clin Invest 2011;121:3981-3990.

257. Khan S, Cleveland RP, Koch CJ, Schelling JR. Hypoxia induces renal tubular epithelial cell apoptosis in chronic renal disease. Lab Invest 1999;79:1089-1099.

258. LeBleu VS, Taduri G, O'Connell J, Teng Y, Cooke VG, Woda C, Sugimoto H, Kalluri R. Origin and function of myofibroblasts in kidney fibrosis. Nat Med 2013;19:1047-1053.

259. Manotham K, Tanaka T, Matsumoto M, Ohse T, Inagi R, Miyata T, Kurokawa K, Fujita T, Ingelfinger JR, Nangaku M. Transdifferentiation of cultured tubular cells induced by hypoxia. Kidney Int 2004;65:871-880.

260. Polichnowski AJ, Lan R, Geng H, Griffin KA, Venkatachalam MA, Bidani AK. Severe renal mass reduction impairs recovery and promotes fibrosis after AKI. J Am Soc Nephrol 2014;25:1496-1507.

261. Kong T, Eltzschig HK, Karhausen J, Colgan SP, Shelley, CS. Leukocyte adhesion during hypoxia is mediated by HIF-1dependent induction of beta 2 integrin gene expression. Proc Natl Acad Sci USA 2004;101:10440-10445.

262. Kong T, Scully M, Shelley, CS, Colgan SP. Identification of Pur alpha as a new hypoxia response factor responsible for coordinated induction of the beta 2 integrin family. $J$ Immunol 2007;179:1934-1941.

263. Zager RA, Johnson AC, Becker K. Acute unilateral ischemic renal injury induces progressive renal inflammation, lipid accumulation, histone modification, and "end-stage" kidney disease. Am J Physiol Renal Physiol 2011;301:F1334-F1345.

264. Zager RA, Johnson AC. Renal ischemia-reperfusion injury upregulates histone-modifying enzyme systems and alters histone expression at proinflammatory/profibrotic genes. Am J Physiol Renal Physiol 2009;296:F1032-F1041.

265. Naito M, Zager RA, Bomsztyk K. BRG1 increases transcription of proinflammatory genes in renal ischemia. $\mathrm{J}$ Am Soc Nephrol 2009;20:1787-1796.

266. Norman JT, Clark IM, Garcia PL. Hypoxia promotes fibrogenesis in human renal fibroblasts. Kidney Int 2000;58:2351-2366.

267. Johnson AB, Denko N, Barton MC. Hypoxia induces a novel signature of chromatin modifications and global repression of transcription. Mutat Res 2008;640:174-179.

268. Zager RA, Johnson AC, Andress D, Becker K. Progressive endothelin-1 gene activation initiates chronic/end-stage renal disease following experimental ischemic/reperfusion injury. Kidney Int 2013;84:703-712.

269. Young T, Palta M, Dempsey J, Skatrud J, Weber S, Badr S. The occurrence of sleep-disordered breathing among middleaged adults. N Eng J Med 1993;328:1230-1235.

270. Markou N, Kanakaki M, Myrianthefs P, Hadjiyanakos D, Vlassopoulos D, Damianos A, Siamopoulos K, Vasiliou M, Konstantopoulos S. Sleep-disordered breathing in nondialyzed patients with chronic renal failure. Lung 2006;184:43-49.

271. Sakaguchi Y, Shoji T, Kawabata H, Niihata K, Suzuki A, Kaneko T, Okada N, Isaka Y, Rakugi H, Tsubakihara Y. High prevalence of obstructive sleep apnea and its association with renal function among nondialysis chronic kidney disease patients in Japan: a cross-sectional study. Clin J Am Soc Nephrol 2011;6:995-1000.

272. Nicholl DD, Ahmed SB, Loewen AH, Hemmelgarn BR, Sola, DY, Beecroft JM, Turin TC, Hanly PJ. Declining kidney function increases the prevalence of sleep apnea and nocturnal hypoxia. Chest 2012;141:1422-1430. 
273. Kanbay A, Buyukoglan H, Ozdogan N, Kaya E, Oymak FS, Gulmez I, Demir R, Kokturk O, Covic A. Obstructive sleep apnea syndrome is related to the progression of chronic kidney disease. Int Urol Nephrol 2012;44:535-539.

274. Fleischmann G, Fillafer G, Matterer H, Skrabal F, Kotanko P. Prevalence of chronic kidney disease in patients with suspected sleep apnoea. Nephrol Dial Transplant 2010;25:181-186.

275. Casserly LF, Chow N, Ali S, Gottlieb DJ, Epstein LJ, Kaufman JS. Proteinuria in obstructive sleep apnea. Kidney Int 2001;60:1484-1489.

276. Faulx MD, Storfer-Isser A, Kirchner HL, Jenny NS, Tracy RP, Redline S. Obstructive sleep apnea is associated with increased urinary albumin excretion. Sleep 2007;30:923-929.

277. Ahmed SB, Ronksley PE, Hemmelgarn BR, Tsai WH, Manns BJ, Tonelli M, Klarenbach SW, Chin R, Clement FM, Hanly PJ. Nocturnal hypoxia and loss of kidney function. PLoS One 2011;6:e19029.

278. Sakaguchi Y, Hatta T, Hayashi T, Shoji T, Suzuki A, Tomida K, Okada N, Rakugi H, Isaka Y, Tsubakihara Y. Association of nocturnal hypoxemia with progression of CKD. Clin J Am Soc Nephrol 2013;8:1502-1507.

279. Abuyassin B, Sharma K, Ayas NT, Laher I. Obstructive sleep apnea and kidney disease: a potential bidirectional relationship. J Clin Sleep Med 2015;11:915-924.

280. Kersh ES, Kronfield SJ, Under A, Popper RW, Cantor S, Cohn $\mathrm{K}$. Autonomic insufficiency in uremia as a cause of hemodialysis-induced hypotension. N Eng J Med 1974;290:650-653.

281. Henrich WL. Hemodynamic instability during hemodialysis. Kidney Int 1986;30:605-612.

282. Beecroft JM, Hoffstein V, Pierratos A, Chan CT, McFarlane PA, Hanly PJ. Pharyngeal narrowing in end-stage renal disease: implications for obstructive sleep apnoea. Eur Respir J 2007;30:965-971.

283. Tang SC, Lam B, Lai AS, Pang CB, Tso WK, Khong PL, Ip MS, Lai KN. Improvement in sleep apnea during nocturnal peritoneal dialysis is associated with reduced airway congestion and better uremic clearance. Clin J Am Soc Nephrol 2009;4:410-418.

284. Tang SC, Lam B, Lam JC, Chan CK, Chow CC, Ho YW, Ip MS, Lai KN. Impact of nephrotic edema of the lower limbs on obstructive sleep apnea: gathering a unifying concept for the pathogenetic role of nocturnal rostral fluid shift. Nephrol Dial Transplant 2012;27:2788-2794.

285. Adeseun GA, Rosas SE. The impact of obstructive sleep apnea on chronic kidney disease. Curr Hypertens Rep 2010;12:378383.

286. Hanly PJ, Ahmed SB. Sleep apnea and the kidney: is sleep apnea a risk factor for chronic kidney disease? Chest 2014;146:1114-1122.

287. Peng YJ, Overholt JL, Kline D, Kumar GK, Prabhakar NR. Induction of sensory long-term facilitation in the carotid body by intermittent hypoxia: implications for recurrent apneas. Proc Natl Acad Sci USA 2003;100:10073-10078.

288. Peng YJ, Yuan G, Ramakrishnan D, Sharma SD, Bosch-Marce M, Kumar GK, Semenza GL, Prabhakar NR. Heterozygous HIF-1alpha deficiency impairs carotid body-mediated systemic responses and reactive oxygen species generation in mice exposed to intermittent hypoxia. J Physiol 2006;577:705-716.

289. Yuan G, Khan SA, Luo W, Nanduri J, Semenza GL, Prabhakar NR. Hypoxia-inducible factor 1 mediates increased expression of NADPH oxidase- 2 in response to intermittent hypoxia. J Cell Physiol 2011;226:2925-2933.

290. Yamauchi M, Nakano H, Maekawa J, Okamoto Y, Ohnishi Y, Suzuki T, Kimura H. Oxidative stress in obstructive sleep apnea. Chest 2005;127:1674-1679.
291. Pialoux V, Hanly PJ, Foster GE, Brugniaux JV, Beaudin AE, Hartmann SE, Pun M, Duggan CT, Poulin MJ. Effects of exposure to intermittent hypoxia on oxidative stress and acute hypoxic ventilatory response in humans. Am J Respir Crit Care Med 2009;180:1002-1009.

292. Sun W, Yin X, Wang Y, Tan Y, Cai L, Wang B, Cai J, Fu Y. Intermittent hypoxia-induced renal antioxidants and oxidative damage in male mice: hormetic dose response. Dose Response 2013;11:385-400.

293. Gilmartin GS, Lynch M, Tamisier R, Weiss JW. Chronic intermittent hypoxia in humans during 28 nights results in blood pressure elevation and increased muscle sympathetic nerve activity. Am J Physiol Heart Circ Physiol 2010;299:H925-H931.

294. Foster GE, Hanly PJ, Ahmed SB, Beaudin AE, Pialoux V, Poulin MJ. Intermittent hypoxia increases arterial blood pressure in humans through a Renin-Angiotensin systemdependent mechanism. Hypertension 2010;56:369-377.

295. Pratt-Ubunama MN, Nishizaka MK, Boedefeld RL, Cofield SS, Harding SM, Calhoun DA. Plasma aldosterone is related to severity of obstructive sleep apnea in subjects with resistant hypertension. Chest 2007;131:453-459.

296. Zalucky AA, Nicholl DD, Hanly PJ, Poulin MJ, Turin TC, Walji S, Handley GB, Raneri JK, Sola DY, Ahmed SB. Nocturnal hypoxemia severity ands renin-angiotensin system activity in obstructive sleep apnea. Am J Respir Crit Care Med 2015;192:873-880.

297. Perry JC, Bergamaschi CT, Campos RR, Andersen ML, Casarini DE, Tufik S. Differential sympathetic activation induced by intermittent hypoxia and sleep loss in rats: action of angiotensin (1-7). Auton Neurosci 2011;160:32-36.

298. Thongboonkerd V, Gozal E, Sachleben LR Jr, Arthur JM, Pierce WM, Cai J, Chao J, Bader M, Pesquero JB, Gozal D, Klein JB. Proteomic analysis reveals alterations in the renal kallikrein pathway during hypoxia-induced hypertension. J Biol Chem 2002;277:34708-34716.

299. Budhiraja R, Parthasarathy S, Quan SF. Endothelial dysfunction in obstructive sleep apnea. J Clin Sleep Med 2007;3:409-415.

300. Peppard PE, Young T, Palta M, Skatrud J. Prospective study of the association between sleep-disordered breathing and hypertension. N Engl J Med 2000;342:1378-1384.

301. Drager LF, Bortolotto LA, Figueiredo AC, Silva BC, Krieger EM, Lorenzi-Filho G. Obstructive sleep apnea, hypertension, and their interaction on arterial stiffness and heart remodeling. Chest 2007;131:1379-1386.

302. Fletcher EC. Invited review: physiological consequences of intermittent hypoxia: systemic blood pressure. J Appl Physiol 2001;90:1600-1605.

303. Morgan BJ. Vascular consequences of intermittent hypoxia. Adv Exp Med Biol 2007;618:69-84.

304. Aldigier JC, Kanjanbuch T, Ma LJ, Brown NJ, Fogo AB. Regression of existing glomerulosclerosis by inhibition of aldosterone. J Am Soc Nephrol 2005;16:3306-3314.

305. Veale D, Pepin JL, Levy PA. Autonomic stress tests in obstructive sleep apnea and snoring. Sleep 1992;15:505-513.

306. Zoccali C, Mallamaci F, Tripepi G, Benedetto FA. Autonomic neuropathy is linked to nocturnal hypoxaemia and to concentric hypertrophy and remodeling in dialysis patients. Nephrol Dial Transplant 2001;16:70-77.

307. Quercioli A, Mach F, Montecucco F. Inflammation accelerates atherosclerotic processes in obstructive sleep apnea syndrome (OSAS). Sleep Breath 2010;14:261-269.

308. Minoguchi K, Yokoe T, Tazaki T, Minoguchi H, Tanaka A, Oda N, Okada S, Ohta S, Naito H, Adachi M. Increased carotid intima-media thickness and serum inflammatory markers in obstructive sleep apnea. Am J Respir Crit Care Med 2005;172:625-630. 
309. Garvey JF, Taylor CT, McNicholas WT. Cardiovascular disease in obstructive sleep apnoea syndrome: the role of intermittent hypoxia and inflammation. Eur Respir J 2009;33:1195-1205.

310. Dempsey JA, Veasey SC, Morgan BJ, O’Donnell CP. Pathophysiology of sleep apnea. Physiol Rev 2010;90:47112.

311. Somers VK, White DP, Amin R, Abraham WT, Costa F, Culebras A, Daniels S, Floras JS, Hunt CE, Olson LJ, Pickering TG, Russell R, Woo M, Young T. Sleep apnea and cardiovascular disease: an American Heart Association/ American College of Cardiology Foundation Scientific Statement from the American Heart Association Council for High Blood Pressure Research Professional Education Committee, Council on Clinical Cardiology, Stroke Council, and Council on Cardiovascular Nursing. J Am Coll Cardiol 2008;52:686-717.

312. Marin JM, Carrizo SJ, Vicente E, Agusti AG. Long-term cardiovascular outcomes in men with obstructive sleep apnoea-hypopnoea with or without treatment with continuous positive airway pressure: an observational study. Lancet 2005;365:1046-1053.

313. Yaggi HK, Concato J, Kerman WN, Lichtman JH, Brass LM, Mohsenin V. Obstructive sleep apnea as a risk factor for stroke and death. N Engl J Med 2005;353:2034-2041.

314. Masuda T, Murata M, Honma S, Iwazu Y, Sasaki N, Ogura M, Onishi A, Ando Y, Muto S, Shimada K, Kario K, Kusano E, Asano Y. Sleep-disordered breathing predicts cardiovascular events and mortality in hemodialysis patients. Nephrol Dial Transplant 2011;26:2289-2295.

315. Tang SC, Lam B, Yao TJ, Leung WS, Chu CM, Ho YW, Ip MS, Lai KN. Sleep apnea is a novel risk predictor of cardiovascular morbidity and death in patients receiving peritoneal dialysis. Kidney Int 2010;77:1031-1038.

316. Jung HH, Lee JH, Baek HJ, Kim SJ, Lee JJ. Nocturnal hypoxemia and periodic limb movement predict mortality in patients on maintenance hemodialysis. Clin J Am Soc Nephrol 2010;5:1607-1613.

317. Lattimore JL, Wilcox I, Skilton M, Langenfeld M, Celermajer DS. Treatment of obstructive sleep apnoea leads to improved microvascular endothelial function in the systemic circulation. Thorax 2006;61:491-495.

318. El Solh AA, Akinnusi ME, Baddoura FH, Mankowski CR. Endothelial cell apoptosis in obstructive sleep apnea: a link to endothelial dysfunction. Am J Respir Crit Care Med 2007; 175:1186-1191

319. Schulz R, Mahmoudi S, Hattar K, Sibelius U, Olschewski H, Mayer K, Seeger W, Grimminger F. Enhanced release of superoxide from polymorphonuclear neutrophils in obstructive sleep apnea. Impact of continuous positive airway pressure therapy. Am J Respir Crit Care Med 2000;162:566570.

320. Yokoe T, Minoguchi K, Matsuo H, Oda N, Minoguchi H, Yoshino G, Hirano T, Adachi M. Elevated levels of C-reactive protein and interleukin-6 in patients with obstructive sleep apnea syndrome are decreased by nasal continuous positive airway pressure. Circulation 2003;107:1129-1134

321. Schulz R, Schmidt D, Blum A, Lopes-Ribeiro X, Lücke C, Mayer K, Olschewski H, Seeger W, Grimminger F. Decreased plasma levels of nitric oxide derivatives in obstructive sleep apnoea: response to CPAP therapy. Thorax 2000;55:1046-1051.

322. Phillips BG, Narkiewicz K, Pesek CA, Haynes WG, Dyken ME, Somers VK. Effects of obstructive sleep apnea on endothelin-1 and blood pressure. J Hypertens 1999;17:61-66.
323. Beguin PC, Belaidi E, Godin-Ribuot D, Levy P, Ribuot C Intermittent hypoxia-induced delayed cardioprotection is mediated by PKC and triggered by $\mathrm{p} 38$ MAP kinase and Erk1/2. J Mol Cell Cardiol 2007;42:343-351.

324. Minet E, Arnould T, Michel G, Roland I, Mottet D, Raes M, Remacle J, Michiels C. ERK activation upon hypoxia: involvement in HIF-1 activation. FEBS Lett 2000;468:53-58.

325. Zou AP, Yang ZZ, Li PL, Cowley AW Jr. Oxygen-dependent expression of hypoxia-inducible factor-1 alpha in renal medullary cells of rats. Physiol Genomics. 2001;6:159-168.

326. Miraliakbari R, Francalancia NA, Lust RM, Gerardo JA, Ng PC, Sun YS, Chitwood WR Jr. Differences in myocardial and peripheral VEGF and KDR levels after acute ischemia. Ann Thorac Surg 2000;69:1750-1753.

327. Kaneko T, Shimizu A, Mii A, Fujita E, Fujino T, Kunugi S, Du X, Akimoto T, Tsuruoka S, Ohashi R, Masuda Y, Iino Y, Katayama Y, Fukuda Y. Role of matrix metalloproteinase-2 in recovery after tubular damage in acute kidney injury in mice. Nephron Exp Nephrol 2012;122:23-35.

328. Leonard MO, Kieran NE, Howell K, Burne MJ, Varadarajan R, Dhakshinamoorthy S, Porter AG, O'Farrelly C, Rabb H, Taylor CT. Reoxygenation-specific activation of the antioxidant transcription factor Nrf2 mediates cytoprotective gene expression in ischemia-reperfusion injury. FASEB J 2006;20:2624-2626.

329. Sharma R, Sharma M, Datta PK, Savin VJ. Induction of metallothionein-I protects glomeruli from superoxidemediated increase in albumin permeability. Exp Biol Med 2002;227:26-31

330. Yang ZZ, Zou AP. Transcriptional regulation of heme oxygenases by HIF-1 alpha in renal medullary interstitial cells. Am J Physiol Renal Physiol 2001;281:F900-F908.

331. Uchida T, Rossignol F, Matthay MA, Mounier R, Couette S, Clottes E, Clerici C. Prolonged hypoxia differentially regulates hypoxia-inducible factor (HIF)-1alpha and HIF2alpha expression in lung epithelial cells: implication of natural antisense HIF-1alpha. J Biol Chem 2004;279:14871-14878.

332. Yang ZZ, Zhang AY, Yi FX, Li PL, Zou AP. Redox regulation of HIF-1alpha levels and HO-1 expression in renal medullary interstitial cells. Am J Physiol Renal Physiol 2003;284:F1207-F1215.

333. Zou AP, Cowley AW Jr. Reactive oxygen species and molecular regulation of renal oxygenation. Acta Physiol Scand 2003;179:233-241.

334. Lu TH, Hsieh SY, Yen CC, Wu HC, Chen KL, Hung DZ, Chen $\mathrm{CH}$, Wu CC, Su YC, Chen YW, Liu SH, Huang CF. Involvement of oxidative stress-mediated ERK1/2 and p38 activation regulated mitochondria-dependent apoptotic signals in methylmercury-induced neuronal cell injury. Toxicol Lett 2011;204:71-80.

335. Nangaku M, Rosenberger C, Heyman SN, Eckardt KU. Regulation of hypoxia-inducible factor in kidney disease. Clin Exp Pharmacol Physiol 2013;40:148-157.

336. Orphanides C, Fine LG, Norman JT. Hypoxia stimulates proximal tubular cell matrix production via a TGF-beta1independent mechanism. Kidney Int 1997;52:637-647.

337. Norman JT, Clark IM, Garcia PL. Hypoxia promotes fibrogenesis in human renal fibroblasts. Kidney Int 2000;58:2351-2366.

338. Falanga V, Zhou L, Yufit T. Low oxygen tension stimulates collagen synthesis and COL1A1 transcription through the action of TGF-beta1. J Cell Physiol 2002;191:42-50.

339. Sanchez-Elsner T, Botella LM, Velasco B, Corbi A, Attisano $\mathrm{L}$, Bernabeu C. Synergistic cooperation between hypoxia and transforming growth factor-beta pathways on human vascular endothelial growth factor gene expression. J Biol Chem 2001;276:38527-38535. 
340. Sanchez-Elsner T, Botella LM, Velasco B, Langa C, Bernabeu C. Endoglin expression is regulated by transcriptional cooperation between the hypoxia and transforming growth factor-beta pathways. J Biol Chem 2002;277:43799-43808.

341. Sanchez-Elsner T, Ramirez JR, Sanz-Rodriguez F, Varela E, Bernabeu C, Botella LM. A cross-talk between hypoxia and TGF-beta orchestrates erythropoietin gene regulation through SP1 and Smads. J Mol Biol 2004;336:9-24.

342. Saed GM, Zhang W, Chegini N, Holmdahl L, Diamond MP. Alteration of type I and III collagen expression in human peritoneal mesothelial cells in response to hypoxia and transforming growth factor-beta 1 . Wound Repair Regen 1999;7:504-510.

343. Kietzmann T, Roth U, Jungermann K. Induction of the plasminogen activator inhibitor-1 gene expression by mild hypoxia via a hypoxia response element binding the hypoxiainducible factor-1 in rat hepatocytes. Blood 1999;94:41774185.

344. Dore-Duffy P, Balabanov R, Beaumont T, Hritz MA, Harik SI, LaManna JC. Endothelial activation following prolonged hypobaric hypoxia. Microvasc Res 1999;57:75-85.

345. Malaponte G, Bevelacqua V, Fatuzzo P, Rapisarda F, Emmanuele G, Travali S, Mazzarino MC. IL-1beta, TNFalpha and IL-6 release from monocytes in haemodialysis patients in relation to dialytic age. Nephrol Dial Transplant 2002; 17:1964-1970.

346. Sean Eardley K, Cockwell P. Macrophages and progressive tubulointerstitial disease. Kidney Int 2005;68:437-455.

347. Albina JE, Henry WL Jr, Mastrofrancesco B, Martin BA, Reichner JS. Macrophage activation by culture in an anoxic environment. J Immunol 1995;155:4391-4396.

348. Lewis JS, Lee JA, Underwood JC, Harris AL, Lewis CE. Macrophage responses to hypoxia: relevance to disease mechanisms. J Leukoc Biol 1999;66:889-900.

349. Luscinskas FW, Ma S, Nusrat A, Parkos CA, Shaw SK. Leukocyte transendothelial migration: a junctional affair. Semin Immunol 2002;14:105-113.

350. Konstantopoulos K, Hanley WD, Wirtz D. Receptor-ligand binding: 'catch' bonds finally caught. Curr Biol 2003;13:R611-R613.

351. Hayflick JS, Kilgannon P, Gallatin WM. The intercellular adhesion molecule (ICAM) family of proteins. New members and novel functions. Immunol Res 1998;17:313327.

352. Van der Vieren M, Le Trong H, Wood CL, Moore PF, St. John T, Staunton DE, Gallatin WM. A novel leukointegrin, alpha d beta 2 , binds preferentially to ICAM-3. Immunity 1995;3:683-690.

353. Mazzone A, Ricevuti G. Leukocyte CD11/CD18 integrins: biological and clinical relevance. Haematologica 1995;80:161-175.

354. King PD, Batchelor AH, Lawlor P, Katz DR. The role of CD44, CD45, CD45RO, CD46 and CD55 as potential antiadhesion molecules involved in the binding of human tonsillar T cells to phorbol 12-myristate 13-acetatedifferentiated U-937 cells. Eur J Immunol. 1990;20:363-368.

355. Manjunath N, Correa M, Ardman M, Ardman B. Negative regulation of T-cell adhesion and activation by CD43. Nature 1995:377:535-538.

356. Woollett GR, Williams AF, Shotton DM. Visualisation by low-angle shadowing of the leucocyte-common antigen. A major cell surface glycoprotein of lymphocytes. EMBO J 1985;4:2827-2830.

357. Cyster JG, Shotton DM, Williams AF. The dimensions of the T lymphocyte glycoprotein leukosialin and identification of linear protein epitopes that can be modified by glycosylation. EMBO J 1991;10:893-902.
358. Clark MC, Baum LG. T cells modulate glycans on CD43 and CD45 during development and activation, signal regulation, and survival. Ann N Y Acad Sci 2012;1253:58-67.

359. Böhm I. Environment-dependent down-modulation of CD45 cell surface expression on polymorphonuclear cells. J Clin Lab Anal 2004;18:187-194.

360. Shelley CS, Böttinger EP, Arnaout MA. Transcriptional regulation of beta 2-integrins. In: Gahmberg CG, MandrupPoulsen T, Wogensen Bach L, Hökfelt B, eds. Leukocyte adhesion: Basic and Clinical Aspects. Amsterdam, The Netherlands: Elsevier Science Publishers;1992. 337-351.

361. Da Silva N, Bharti A, Shelley CS. hnRNP-K and Pur alpha act together to repress the transcriptional activity of the CD43 gene promoter. Blood 2002;100:3536-3544.

362. Shelley CS, Da Silva N, Teodoridis JM. During U937 monocytic differentiation repression of the CD43 gene promoter is mediated by the single-stranded DNA binding protein Pura. Br J Haematol 2001;115:159-166.

363. Bazil V, Strominger JL. CD43, the major sialoglycoprotein of human leukocytes, is proteolytically cleaved from the surface of stimulated lymphocytes and granulocytes. Proc Natl Acad Sci USA 1993;90:3792-3796.

364. Stewart M, Hogg N. Regulation of leukocyte integrin function: affinity vs. avidity. J Cell Biochem 1996;61:554-561.

365. Springer TA, Anderson DC. The importance of the Mac-1, LFA-1 glycoprotein family in monocyte and granulocyte adherence, chemotaxis, and migration into inflammatory sites: insights from an experiment of nature. Ciba Found Symp 1986;118:102-126.

366. Shelley CS, Farokhzad OC, Arnaout, MA. Identification of cell-specific and developmentally-regulated nuclear factors which direct myeloid and lymphoid expression of the CD11a gene. Proc Natl Acad Sci USA 1993;90:5364-5368.

367. Shelley CS, Arnaout MA. The promoter of the CD11b gene directs myeloid specific and developmentally-regulated expression. Proc Natl Acad Sci USA 1991;88:10525-10529.

368. Shelley CS, Teodoridis JM, Park H, Farokhzad OC, Böttinger EP, Arnaout MA. During differentiation of the monocytic cell line U937, Pur alpha mediates induction of the CD11c gene promoter. J Immunol 2002;168:3887-3893.

369. Böttinger EP, Shelley CS, Farokhzad OC, Arnaout MA. The human beta 2 integrin CD18 promoter consists of two inverted Ets cis elements. Mol Cell Biol 1994;14:2604-2615.

370. Farokhzad OC, Shelley CS, Böttinger EP, Arnaout MA. Induction of the $\mathrm{CD} 11 \mathrm{~b}$ gene during myeloid differentiation requires its interaction with the novel transcription factor MS-2. J Immunol 1996;157:5597-5605.

371. Nicolaou F, Teodoridis JM, Park H, Georgakis A, Farokhzad OC, Böttinger EP, Da Silva N, Rousselot P, Chomienne C, Ferenczi K, Arnaout MA, Shelley CS. CD11c gene expression in hairy-cell leukemia is dependent upon activation of the proto-oncogenes ras and junD. Blood 2003;101:4033-4041.

372. Campbell EL, Bruyninckx WJ, Kelly CJ, Glover LE, McNamee EN, Bowers BE, Bayless AJ, Scully M, Saeedi BJ, Golden-Mason L, Ehrentraut SF, Curtis VF, Burgess A, Garvey JF, Sorensen A, Nemenoff R, Jedlicka P, Taylor CT, Kominsky DJ, Colgan SP. Transmigrating neutrophils shape the mucosal microenvironment through localized oxygen depletion to influence resolution of inflammation. Immunity 2014;40:66-77.

373. de Dios I, Ramudo L, Garcia-Montero AC, Manso MA. Redox-senstitive modulation of CD45 expression in pancreatic acinar cells during acute pancreatitis. J Pathol 2006;210:234-239.

374. Remold-O'Donnell E, Parent D. Downregulation of neutrophil CD43 by opsonized zymosan. Blood 1995;85:337-342. 
375. Hochman ME, Watt JP, Reid R, O'Brien KL. The prevalence and incidence of end-stage renal disease in Native American adults on the Navajo reservation. Kidney Int 2007;71:931-937.

376. Chen W, Liu Q, Wang H, Chen W, Johnson RJ, Dong X, Li H, Ba S, Tan J, Luo N, Liu T, He H, Yu X. Prevalence and risk factors of chronic kidney disease: a population study in the Tibetan population. Nephrol Dial Transplant 2011;26:1592-1599.

377. Masuda T, Honma S, Sasaki N, Hanawa-Yazawa S, Iwazu Y, Kusano E, Asano Y. Effect of continuous positive airway pressure on proteinuria in obstructive sleep apnea. Clin Kidney J 2012;5:257-260.

378. An J, Devaney B, Ooi KY, Ford S, Frawley G, Menahem S. Hyperbaric oxygen in the treatment of calciphylaxis: a case series and literature review. Nephrology (Carlton) 2015;20:444-450.

379. Ishikawa M, Kobayashi N, Sugiyama F, Onoda S, Ishimitsu T. Renoprotective effect of vasopressin v2 receptor antagonist tolvaptan in Dahl rats with end-stage heart failure. Int Heart J 2013;54:98-106.

380. Renke M, Lizakowski S, Tylicki L, Rutkowski P, Knap N, Heleniak Z, Sławińska-Morawska M, Aleksandrowicz-Wrona E, Januszczyk J, Wójcik-Stasiak M, Małgorzewicz S, Woźniak M, Rutkowski B. Aliskiren attenuates oxidative stress and improves tubular status in non-diabetic patients with chronic kidney disease-Placebo controlled, randomized, cross-over study. Adv Med Sci 2014;59:256-260.

381. Juncos LI, Caputo J. Combination therapy in chronic kidney disease? Ther Adv Cardiovasc Dis 2015;9:147-152.

382. Hayashi K, Homma K, Wakino S, Tokuyama H, Sugano N, Saruta T, Itoh H.T-type Ca channel blockade as a determinant of kidney protection. Keio J Med 2010;59:84-95.

383. Andress DL, Coll B, Pritchett Y, Brennan J, Molitch M, Kohan DE. Clinical efficacy of the selective endothelin A receptor antagonist, atrasentan, in patients with diabetes and chronic kidney disease (CKD) Life Sci 2012;91:739-742.

384. Gassanov N, Nia AM, Caglayan E, Er F. Remote ischemic preconditioning and renoprotection: from myth to a novel therapeutic option? J Am Soc Nephrol 2014;25:216-224.

385. Mahfoudh-Boussaid A, Zaouali MA, Hadj-Ayed K, Miled AH, Saidane-Mosbahi D, Rosello-Catafau J, Ben Abdennebi H. Ischemic preconditioning reduces endoplasmic reticulum stress and upregulates hypoxia inducible factor- $1 \alpha$ in ischemic kidney: the role of nitric oxide. J Biomed Sci 2012;19:7.

386. Ma D, Lim T, Xu J, Tang H, Wan Y, Zhao H, Hossain M, Maxwell PH, Maze M. Xenon preconditioning protects against renal ischemic-reperfusion injury via HIF-1alpha activation. J Am Soc Nephrol 2009;20:713-720.

387. Zhang L, Huang H, Cheng J, Liu J, Zhao H, Vizcaychipi MP, Ma D. Pre-treatment with isoflurane ameliorates renal ischemic-reperfusion injury in mice. Life Sci 2011;88:1102-1107.

388. Bernhardt WM, Câmpean V, Kany S, Jürgensen JS, Weidemann A, Warnecke C, Arend M, Klaus S, Günzler V, Amann K, Willam C, Wiesener MS, Eckardt KU. Preconditional activation of hypoxia-inducible factors ameliorates ischemic acute renal failure. J Am Soc Nephrol 2006;17:1970-1978.

389. Weidemann A, Bernhardt WM, Klanke B, Daniel C, Buchholz B, Câmpean V, Amann K, Warnecke C, Wiesener MS, Eckardt KU, Willam C. HIF activation protects from acute kidney injury. J Am Soc Nephrol 2008;19:486-494.

390. Matsumoto M, Makino Y, Tanaka T, Tanaka H, Ishizaka N, Noiri E, Fujita T, Nangaku M. Induction of renoprotective gene expression by cobalt ameliorates ischemic injury of the kidney in rats. J Am Soc Nephrol 2003;14:1825-1832.
391. Kaelin WG, Jr., Ratcliffe PJ. Oxygen sensing by metazoans: the central role of the HIF hydroxylase pathway. Mol Cell 2008;30:393-402.

392. Mole DR, Schlemminger I, McNeill LA, Hewitson KS, Pugh CW, Ratcliffe PJ, Schofield CJ. 2-oxoglutarate analogue inhibitors of HIF prolyl hydroxylase. Bioorg Med Chem Lett 2003;13:2677-2680.

393. Epstein AC, Gleadle JM, McNeill LA, Hewitson KS, O'Rourke J, Mole DR, Mukherji M, Metzen E, Wilson MI, Dhanda A, Tian YM, Masson N, Hamilton DL, Jaakkola P, Barstead R, Hodgkin J, Maxwell PH, Pugh CW, Schofield CJ, Ratcliffe PJ. C. elegans EGL-9 and mammalian homologs define a family of dioxygenases that regulate HIF by prolyl hydroxylation. Cell 2001;107:43-54.

394. Hirsilä M, Koivunen P, Günzler V, Kivirikko KI, Myllyharju J. Characterization of the human prolyl 4-hydroxylases that modify the hypoxia-inducible factor. J Biol Chem 2003; 278:30772-30780.

395. Schlemminger I, Mole DR, McNeill LA, Dhanda A, Hewitson KS, Tian YM, Ratcliffe PJ, Pugh CW, Schofield CJ. Analogues of dealanylalahopcin are inhibitors of human HIF prolyl hydroxylases. Bioorg Med Chem Lett 2003; 13:1451-1454.

396. Flight MH. Deal watch: AstraZeneca bets on FibroGen's anaemia drug. Nat Rev Drug Discov 2013;12:730

397. Cohen DL, Townsend RR. Is there added value to adding ARB to ACE inhibitors in the management of CKD? J Am Soc Nephrol 2009;20:1666-1668.

398. Tylicki L, Rutkowski P, Renke M, Larczyński W, Aleksandrowicz E, Lysiak-Szydlowska W, Rutkowski B. Triple pharmacological blockade of the renin-angiotensinaldosterone system in nondiabetic CKD: an open-label crossover randomized controlled trial. Am J Kidney Dis 2008;52:486-493.

399. Ayoub MA, Zhang Y, Kelly RS, See HB, Johnstone EK, McCall EA, Williams JH, Kelly DJ, Pfleger KD. Fuctional interaction between angiotensin II receptor type 1 and chemokine (C-C motif) receptor 2 with implications for chronic kidney disease. PLoS One 2015;10:e0119803.

400. Leonard EC, Friedrich JL, Basile DP. VEGF-121 preserves renal microvessel structure and ameliorates secondary renal disease following acute kidney injury. Am J Physiol Renal Physiol 2008;295:F1648-F1657.

401. Jung YJ, Kim DH, Lee AS, Lee S, Kang KP, Lee SY, Jang KY, Sung MJ, Park SK, Kim W. Peritubular capillary preservation with COMP-angiopoietin-1 decreases ischemiareperfusion-induced acute kidney injury. Am J Physiol Renal Physiol 2009;297:F952-F960.

402. Long J, Wang Y, Wang W, Chang BH, Danesh FR. Identification of microRNA-93 as a novel regulator of vascular endothelial growth factor in hyperglycemic conditions. J Biol Chem 2010;285:23457-23465.

403. Eirin A, Ebrahimi B, Zhang X, Zhu XY, Woollard JR, He Q, Textor SC, Lerman A, Lerman LO. Mitochondrial protection restores renal function in swine atherosclerotic renovascular disease. Cardiovasc Res 2014;103:461-471.

404. Chen JF, Liu H, Ni HF, Lv LL, Zhang MH, Zhang AH, Tang $\mathrm{RN}$, Chen PS, Liu BC.

Improved mitochondrial function underlies the protective effect of pirfenidone against tubulointerstitial fibrosis in 5/6 nephrectomized rats. PLoS One 2013;8:e83593.

405. Yang Y, Wang J, Qin L, Shou Z, Zhao J, Wang H, Chen Y, Chen J. Rapamycin prevents early steps of the development of diabetic nephropathy in rats. Am J Nephrol 2007;27:495-502.

406. Chade AR, Rodriguez-Porcel M, Herrmann J, Zhu X, Grande JP, Napoli C, Lerman A, Lerman LO. Antioxidant intervention blunts renal injury in experimental renovascular disease. J Am Soc Nephrol 2004;15:958-966. 
407. Vaziri ND, Liu S, Farzaneh SH, Nazertehrani S, Khazaeli M, Zhao YY. Dose-dependent deleterious and salutary actions of the Nrf2 inducer dh404 in chronic kidney disease. Free Radic Biol Med 2015;86:374-381.

408. Friederich M, Fasching A, Hansell P, Nordquist L, Palm F. Diabetes-induced up- regulation of uncoupling protein-2 results in increased mitochondrial uncoupling in kidney proximal tubular cells. Biochim Biophys Acta 2008;1777:935-940.

409. Elmarakby AA, Faulkner J, Baban B, Saleh MA, Sullivan JC. Induction of hemeoxygenase-1 reduces glomerular injury and apoptosis in diabetic spontaneously hypertensive rats. Am J Physiol Renal Physiol. 2012;302:F791-F800.

410. Wong M, Saad S, Zhang J, Gross S, Jarolimek W, Schilter H, Chen JA, Gill AJ, Pollock CA, Wong MG. Semicarbazidesensitive amine oxidase (SSAO) inhibition ameliorates kidney fibrosis in a unilateral ureteral obstruction murine model. Am J Physiol Renal Physiol 2014;307:F908-F916.

411. Lee JH, Kim JH, Kim JS, Chang JW, Kim SB, Park JS, Lee SK. AMP-activated protein kinase inhibits TGF- $\beta-$, angiotensin II-, aldosterone-, high glucose-, and albumininduced epithelial-mesenchymal transition. Am J Physiol Renal Physiol 2013;304:F686-F697.

412. Moningka NC, Tsarova T, Sasser JM, Baylis C. Protective actions of nebivolol on chronic nitric oxide synthase inhibition-induced hypertension and chronic kidney disease in the rat: a comparison with angiotensin II receptor blockade. Nephrol Dial Transplant 2012;27:913-920.

413. Renke M, Tylicki L, Rutkowski P, Knap N, Zietkiewicz M, Neuwelt A, Aleksandrowicz E, Łysiak-Szydłowska W, Woźniak M, Rutkowski B. Effect of pentoxifylline on proteinuria, markers of tubular injury and oxidative stress in non-diabetic patients with chronic kidney disease - placebo controlled, randomized, cross-over study. Acta Biochim Pol 2010;57:119-123.

414. Elmarakby AA, Faulkner J, Pye C, Rouch K, Alhashim A, Maddipati KR, Baban B.Role of haem oxygenase in the renoprotective effects of soluble epoxide hydrolase inhibition in diabetic spontaneously hypertensive rats. Clin Sci 2013;125:349-359.

415. DuPont JJ, Ramick MG, Farquhar WB, Townsend RR, Edwards DG. NADPH oxidase-derived reactive oxygen species contribute to impaired cutaneous microvascular function in chronic kidney disease. Am J Physiol Renal Physiol 2014;306:F1499-F1506.

416. Bayomi HS, Elsherbiny NM, El-Gayar AM, Al-Gayyar MM. Evaluation of renal protective effects of inhibiting TGF- $\beta$ type I receptor in a cisplatin-induced nephrotoxicity model. Eur Cytokine Netw 2013;24:139-147.

417. Sankaran D, Bankovic-Calic N, Ogborn MR, Crow G, Aukema HM. Selective COX-2 inhibition markedly slows disease progression and attenuates altered prostanoid production in Han:SPRD-cy rats with inherited kidney disease. Am J Physiol Renal Physiol 2007;293:F821-F830.

418. Villanueva S, Carreño JE, Salazar L, Vergara C, Strodthoff R, Fajre F, Céspedes C, Sáez PJ, Irarrázabal C, Bartolucci J, Figueroa F, Vio CP. Human mesenchymal stem cells derived from adipose tissue reduce functional and tissue damage in a rat model of chronic renal failure. Clin Sci 2013;125:199-210.

419. Aroor A, McKarns S, Nistala R, Demarco V, Gardner M, Garcia-Touza M, Whaley-Connell A, Sowers JR. DPP-4 inhibitors as therapeutic modulators of immune cell function and associated cardiovascular and renal insulin resistance in obesity and diabetes. Cardiorenal Med 2013;3:48-56.

420. Impellizzeri D, Esposito E, Attley J, Cuzzocrea S. Targeting inflammation: new therapeutic approaches in chronic kidney disease (CKD). Pharmacol Res 2014;81:91-102.
421. Duffield JS, Hong S, Vaidya VS, Lu Y, Fredman G, Serhan $\mathrm{CN}$, Bonventre JV. Resolvin D series and protectin D1 mitigate acute kidney injury. J Immunol 2006;177:59025911.

422. Peng A, Gu Y, Lin SY. Herbal treatment for renal diseases. Ann Acad Med Singapore 2005;34:44-51.

423. Ng YY, Hou CC, Wang W, Huang XR, Lan HY. Blockade of NFkB activation and renal inflammation by ultrasoundmediated gene transfer of Smad7 in rat remnant kidney. Kidney Int Suppl 2005;94:S83-S91.

424. Anders HJ, Ninichuk V, Schlöndorff D. Progression of kidney disease: blocking leukocyte recruitment with chemokine receptor CCR1 antagonists. Kidney Int 2006;69:29-32.

425. Seok SJ, Lee ES, Kim GT, Hyun M, Lee JH, Chen S, Choi R, Kim HM, Lee EY, Chung CH. Blockade of CCL2/CCR2 signalling ameliorates diabetic nephropathy in $\mathrm{db} / \mathrm{db}$ mice. Nephrol Dial Transplant 2013;28:1700-1710.

426. Huart A, Klein J, Gonzalez J, Buffin-Meyer B, Neau E, Delage C, Calise D, Ribes D, Schanstra JP, Bascands JL. Kinin B1 receptor antagonism is equally efficient as angiotensin receptor 1 antagonism in reducing renal fibrosis in experimental obstructive nephropathy, but is not additive. Front Pharmacol 2015;6:8.

427. Liu H, Zhang XP, Yi ZW. Efficacy of antisense monocyte chemoattractant protein-1 (MCP-1) in a rat model of mesangial proliferative glomerulonephritis. Ren Fail 2013;35:1418-1428.

428. Remuzzi G, Perico N, Macia M, Ruggenenti P. The role of renin-angiotensin-aldosterone system in the progression of chronic kidney disease. Kidney Int Suppl 2005;99:S57-S65.

429. Dai Y, Zhang W, Wen J, Zhang Y, Kellems RE, Xia Y. A2B adenosine receptor-mediated induction of IL-6 promotes CKD. J Am Soc Nephrol 2011;22:890-901.

430. Falke LL, Goldschmeding R, Nguyen TQ. A perspective on anti-CCN2 therapy for chronic kidney disease. Nephrol Dial Transplant 2014;29 Suppl 1:i30-i37.

431. Liu N, Guo JK, Pang M, Tolbert E, Ponnusamy M, Gong R, Bayliss G, Dworkin LD, Yan H, Zhuang S. Genetic or pharmacologic blockade of EGFR inhibits renal fibrosis. J Am Soc Nephrol 2012;23:854-867.

432. Boor P, Konieczny A, Villa L, Kunter U, van Roeyen CR, LaRochelle WJ, Smithson G, Arrol S, Ostendorf T, Floege J. PDGF-D inhibition by CR002 ameliorates tubulointerstitial fibrosis following experimental glomerulonephritis. Nephrol Dial Transplant 2007;22:1323-1331.

433. Hao S, He W, Li Y, Ding H, Hou Y, Nie J, Hou FF, Kahn M, Liu Y. Targeted inhibition of $\beta$-catenin/CBP signaling ameliorates renal interstitial fibrosis. J Am Soc Nephrol 2011;22:1642-1653.

434. Kelly DJ, Edgley AJ, Zhang Y, Thai K, Tan SM, Cox AJ, Advani A, Connelly KA, Whiteside CI, Gilbert RE. Protein kinase $C-\beta$ inhibition attenuates the progression of nephropathy in non-diabetic kidney disease. Nephrol Dial Transplant 2009;24:1782-1790.

435. Huang C, Pollock CA, Chen XM. KCa3.1: a new player in progressive kidney disease. Curr Opin Nephrol Hypertens 2015;24:61-66.

436. Chen LH, Advani SL, Thai K, Kabir MG, Sood MM, Gibson IW, Yuen DA, Connelly KA, Marsden PA, Kelly DJ, Gilbert RE, Advani A. SDF-1/CXCR4 signaling preserves microvascular integrity and renal function in chronic kidney disease. PLoS One 2014;9:e92227.

437. Iekushi K, Taniyama Y, Azuma J, Sanada F, Kusunoki H, Yokoi T, Koibuchi N, Okayama K, Rakugi H, Morishita R. Hepatocyte growth factor attenuates renal fibrosis through TGF- $\beta 1$ suppression by apoptosis of myofibroblasts. J Hypertens 2010;28:2454-2461. 
438. Petrova DT, Brandhorst G, Brehmer F, Gross O, Oellerich M, Armstrong VW. Mycophenolic acid displays IMPDHdependent and IMPDH-independent effects on renal fibroblast proliferation and function. Ther Drug Monit 2010;32:405-412.

439. Zeisberg M, Kalluri R. Reversal of experimental renal fibrosis by BMP7 provides insights into novel therapeutic strategies for chronic kidney disease. Pediatr Nephrol 2008;23:13951398.

440. Soma J, Sugawara T, Huang YD, Nakajima J, Kawamura M. Tranilast slows the progression of advanced diabetic nephropathy. Nephron 2002;92:693-698.

441. Liu C, Mei W, Tang J, Yuan Q, Huang L, Lu M, Wu L, Peng Z, Meng J, Yang H, Shen H, Lv B, Hu G, Tao L. Mefunidone attenuates tubulointerstitial fibrosis in a rat model of unilateral ureteral obstruction. PLoS One 2015;10:e0129283.

442. Bielesz B, Sirin Y, Si H, Niranjan T, Gruenwald A, Ahn S, Kato H, Pullman J, Gessler M, Haase VH, Susztak K. Epithelial Notch signaling regulates interstitial fibrosis development in the kidneys of mice and humans. J Clin Invest 2010;120:4040-4054.

443. Olzinski AR, McCafferty TA, Zhao SQ, Behm DJ, Eybye ME, Maniscalco K, Bentley R, Frazier KS, Milliner CM, Mirabile RC, Coatney RW, Willette RN. Hypertensive target organ damage is attenuated by a p38 MAPK inhibitor: role of systemic blood pressure and endothelial protection. Cardiovasc Res 2005;66:170-178.

444. Jin Y, Ratnam K, Chuang PY, Fan Y, Zhong Y, Dai Y, Mazloom AR, Chen EY, D’Agati V, Xiong H, Ross MJ, Chen N, Ma'ayan A, He JC. A systems approach identifies HIPK2 as a key regulator of kidney fibrosis. Nat Med 2012;18:580-588.

445. Hayakawa S, Ohashi K, Shibata R, Kataoka Y, Miyabe M, Enomoto T, Joki Y, Shimizu Y, Kambara T, Uemura Y, Yuasa D, Ogawa H, Matsuo K, Hiramatsu-Ito M, van den Hoff MJ, Walsh K, Murohara T, Ouchi N. Cardiac myocyte-derived follistatin-like 1 prevents renal injury in a subtotal nephrectomy model. J Am Soc Nephrol 2015;26:636-646.

446. Dellê H, Rocha JR, Cavaglieri RC, Vieira JM Jr, Malheiros DM, Noronha IL.Antifibrotic effect of tamoxifen in a model of progressive renal disease. J Am Soc Nephrol 2012;23:37-48.

447. Saglam F, Celik A, Tayfur D, Cavdar Z, Yilmaz O, Sarioglu S, Kolatan E, Oktay G, Camsari T. Decrease in cell proliferation by an matrix metalloproteinase inhibitor, doxycycline, in a model of immune-complex nephritis. Nephrology 2010;15:560-567.

448. Kapitsinou PP, Jaffe J, Michael M, Swan CE, Duffy KJ, Erickson-Miller CL, Haase VH. Preischemic targeting of HIF prolyl hydroxylation inhibits fibrosis associated with acute kidney injury. Am J Physiol Renal Physiol 2012;302:F1172-F1179.

449. Schley G, Klanke B, Schödel J, Forstreuter F, Shukla D, Kurtz A, Amann K, Wiesener MS, Rosen S, Eckardt KU, Maxwell $\mathrm{PH}$, Willam C. Hypoxia-inducible transcription factors stabilization in the thick ascending limb protects against ischemic acute kidney injury. J Am Soc Nephrol 2011;22:2004-2015.

\section{Author Affiliations}

Qiangwei Fu, MD*; Sean P Colgan, PhD"; and Carl Simon Shelley, D.Phil ${ }^{\star 1}$

"Kabara Cancer Research Institute, La Crosse, WI

'Mucosal Inflammation Program and University of Colorado School of Medicine, Aurora, CO

*University of Wisconsin School of Medicine and Public Health, Madison, WI

${ }^{I}$ Current affiliation: Leukemia Therapeutics LLC, Hull, MA 